\title{
Quality of Parent-Child and Sibling Relationships in Families of Children with Symptoms of Oppositional Defiant Disorder
}

\author{
Faeze Khodakarami Janbaz ${ }^{1}$, Abbas Ali Hossein Khanzadeh*2, Abbas Abolghasemi ${ }^{3}$ \\ 1. M.A. Student of General Psychology, Faculty of Literature and Humanities, University of Guilan, Rasht, Iran \\ 2. Associate Professor, Department of Psychology, Faculty of Literature and Humanities, University of Guilan, Rasht, Iran \\ 3. Professor, Department of Psychology, Faculty of Literature and Humanities, University of Guilan, Rasht, Iran
}

Received: February 7, 2018

Accepted: July 12, 2018

\begin{abstract}
Background and Purpose: Oppositional defiant disorder is one of the most common behavioral disorders in children, which causes severe destruction of the child's interpersonal relationships. Therefore, the aim of this study was to investigate the parent-child and sibling relationships quality in families with and without children with symptoms of oppositional defiant disorder.

Method: The design of this research is a causal-comparative. The statistical population included all male and female students of elementary school (from grade three to six) with and without symptoms of oppositional defiant disorder in Rudsar in the academic year of 2017-18, and the sample included 130 of them (65 students in each group) who were selected through convenient sampling method. The tools used for this research included the oppositional defiant disorder rating scale (Hommersen \& et al, 2006), parent-child relationship scale (PCRS) (Fine \& et al, 1983), sibling inventory of behavior (SIB) (Hetherington \& et al, 1999), and clinical interview. Data were analyzed using t-test and multivariate analysis of variance.

Results: The results showed that there is a significant difference between the group with and without symptoms of oppositional defiant disorder in terms of quality of father-child relationship, mother-child relationship, parent-child relationship, as well as the sibling relationships. The mean of group with symptoms of oppositional defiant disorder in each of these variables was significantly less than the group without symptoms of disorder $(\mathrm{P}<0.001)$.

Conclusion: The behaviors of a child with oppositional defiant disorder, mutually, lead to inappropriate parenting behaviors and conflicts between siblings, and, as a result, weaken the quality of relationships between family members.
\end{abstract}

Keywords: Oppositional defiant disorder, parent-child relationships, sibling relationships

Citation: Khodakarami Janbaz F, Hosseinkhanzadeh AA, Abolghasemi A. Quality of parent-child and sibling relationships in families of children with symptoms of oppositional defiant disorder. Quarterly Journal of Child Mental Health. 2019; 6(1): 95-111.

*Corresponding author: Abbas Ali Hossein Khanzadeh, Associate Professor, Department of Psychology, Faculty of Literature and Humanities, University of Guilan, Rasht, Iran.

Email: Abbaskhanzade@gmail.com $\quad$ Tel: (+98) 013-33333217 


\title{
كيفيت رابطهُ والد-كودك و خواهر - برادر در خانوادههاى داراى فرزند مبتلا به نشانهاى اختلال نافرمانى مقابلهاى
}

\author{
فائزه خداكر مى جانباز '، عباسعلى حسين خانزاده*'، عباس ابوالقاسمى \\ ا. كارشناسى ارشد روانشناسى عمومى، دانشكده ادبيات و علوم انسانى، دانشكاه كيلان، رشت، ايران

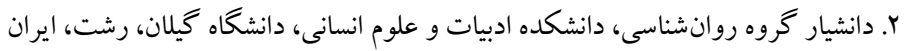

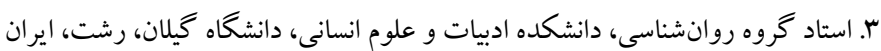

تاريخ يذيرش:

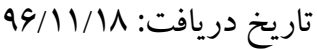

\section{جكيله}

زمينه و هدف: اختلـال نافرمانى مقابلهاى يكى از شـايع ترين اختلالات رفتارى در كود كان اســت كه موجب تخريب شـــــد روابط بينفردى كودكك مى شود. از اينرو هدف يُزوهش حاضـر مطالعه كيفيت رابطة والد-كودكك و خواهر -برادر در خانوادههاى با و بدون فرزند مبتلا به نشانهاى اختلال نافرمانى مقابلهاى بود.

روش: طرح اين يثزوهش، توصسيفى از نوع علّى -مقايسـهاى اسـت. جامعه آمارى شـامل تمامى دانش آموزان دختر و يسـر مقطع ابتدايى

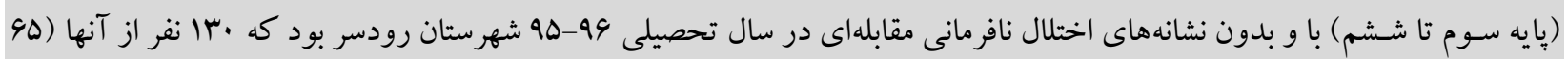

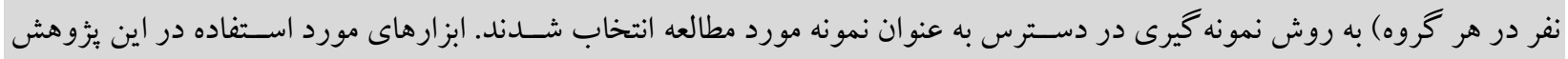

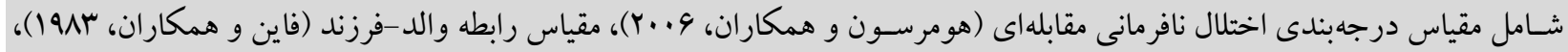

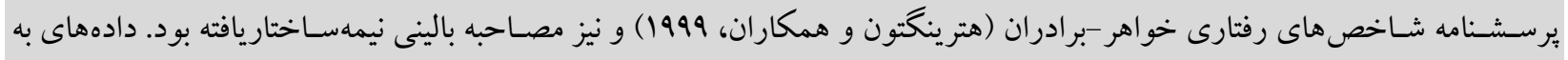

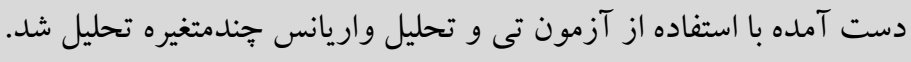

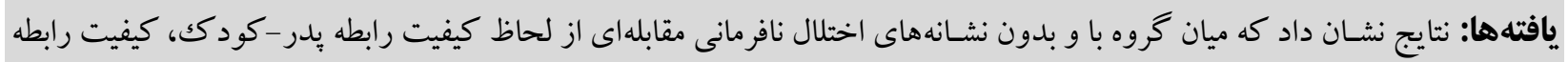

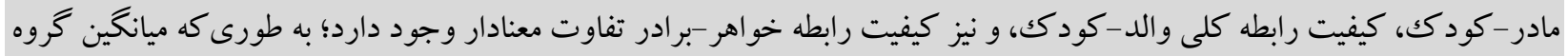

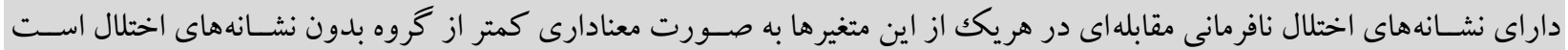

$(\mathrm{P}<\bullet / \cdot \cdot 1)$ نتيجه كيرى: رفتارهاى كود كك مبتلا به اختلال نافرمانى مقابلهاى، به طور متقابل، منجر به رفتارهاى والدگرى نامناسـب از سـوى بدر و و مادر، تعارضات بين خواهر و برادر و در نتيجه تضعيف كيفيت روابط بين اعضاى خانواده مى شود. كليدوازهها: اختلال نافرمانى مقابلهاى، كيفيت رابطه والد-كود كك، كيفيت رابطه خو اهر -برادر

*نويسنده مسئول: عباسعلى حسين خانزاده، دانشيار گروه روانشناسى، دانشكده ادبيات و علوم انسانى، دانشخاه گيلان، رشت، ايران. 
مطالعـات مختلف، نشــان دادنـد كـه نوع رفتار والدين و

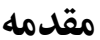

كيفيت رابطه والد-كودكك تأثير بسيار مهمى در بروز و تشديد

اختلالات رفتارى كود كان فشار قابل توجهى را بر فرد، خانواده،

نشانه هاى اختلال نافرمانى مقابلهاى داشته و به طور قابل توجهى

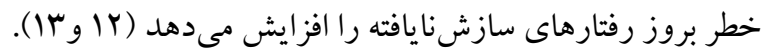

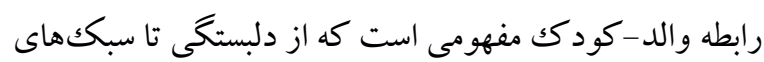
سـنى والدگرى را شامل مىشود و جنبه هايى از اقتدارطلبى در

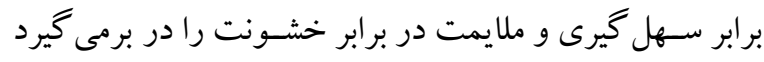

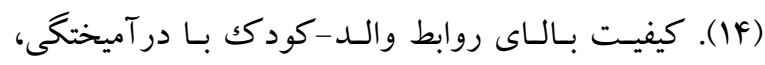
سـاختار و احترام متقابل زياد، و تعارض كم مشـخص مىشود؛

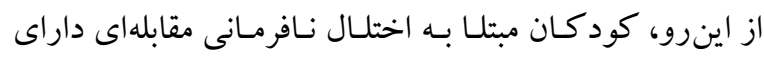
كيفيت روابط والد-كو دكى ضسعيف ترى هستيند، زيرا تعارض

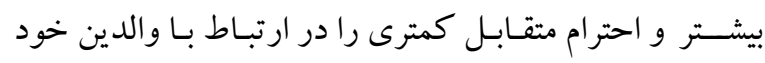
تجربه مى كنند (ها). بيشتر شواهد تجربى، تأثير منفى بدرفتارى والدين را با مشكلات عاطفى و رفتارى كود كان مبتلا به اختلال

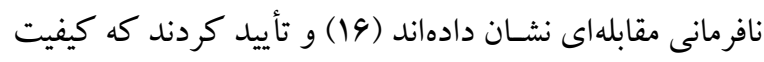
تعاملات والد-كودكك در خانو ادهاى اين كود كان، ضعيفتر و نامناســبتر اسـت (IV) و رفتار والدينى و كيفيت تعاملات

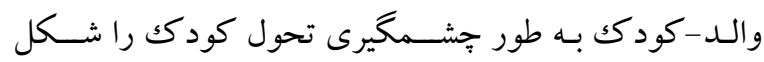

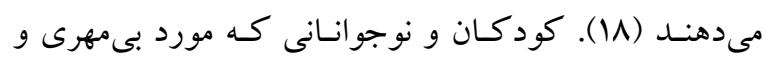
محروميـت عـاطفى قرار مى گيرنــ، رفتـارهـاى تضــادورزانه،

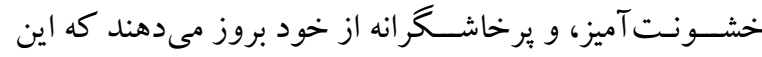
علائم در كود كان داراى اختلال نافرمانى مقابلهاى نمود بيشترى

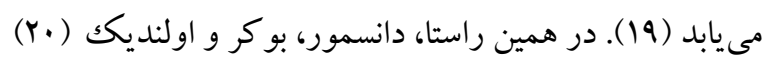

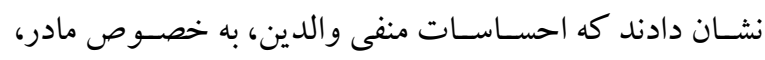

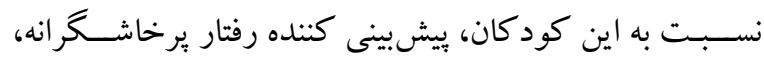

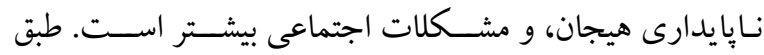
يُزو هش بهروزى، فرزادى و فرامرزى (YI) خشــونت عاطفى و

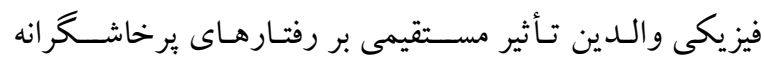

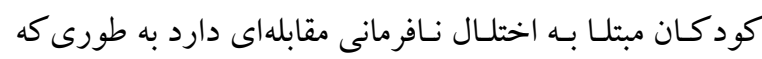

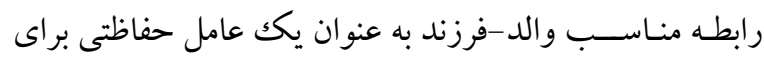


از نزديك با يكديگر آشنايى دارند (ه)). رابطه خو اهر -بر ادرها

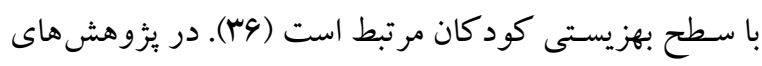

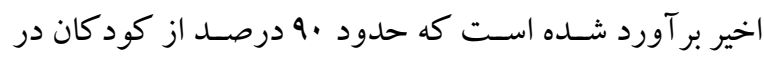

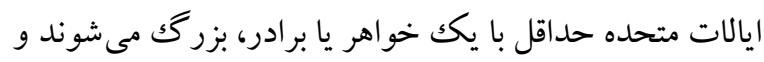

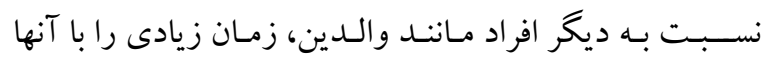

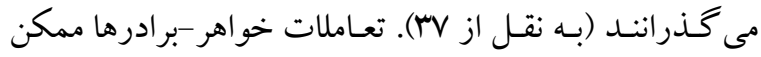

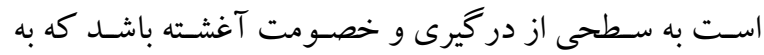

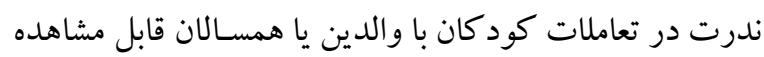

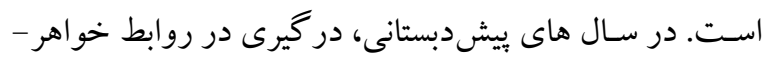

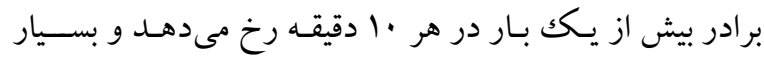
متداول اسـت (N^). مطالعات محدودى وجود دارد كه نشــان مى دهد كود كان مبتلا به اختلال نافرمانى مقابلهاى، در مقايسه با مدان

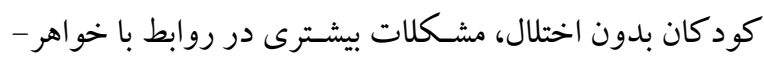
بر ادرها يشـان نشـان مى دهند (19). اما برخى يثروهش ها نشـان

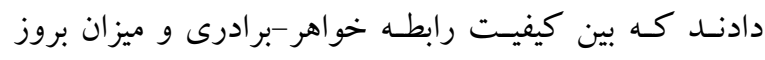

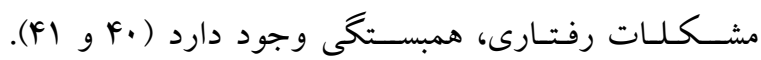

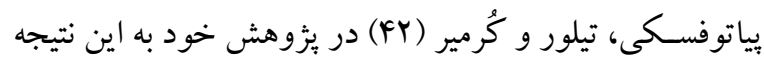

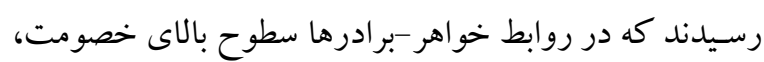
سـطوح هيايين صسميميت، و سـطوح بالاى قطع روابط هر كدام

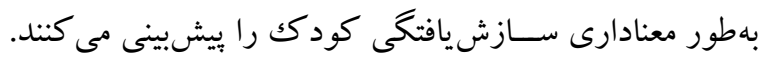
محبت و علاقه ميان خواهر-برادرها در دوران كودكى به طور مثبت و معنادارى با همدلى و رفتارهاى اجتماع يسـند بد در دوره

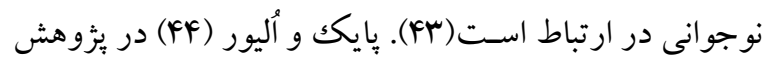

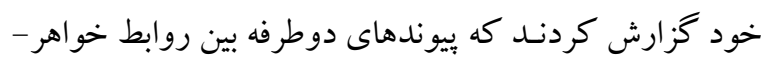
بر ادر و مشكلات رفتارى كود كان معنادار هستند. آنها دريافتند كـه رفتـار شــخصى كودك يِيشينى كنتـده كيفيت روابط

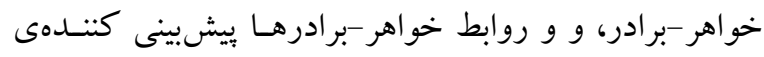

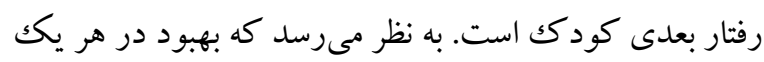

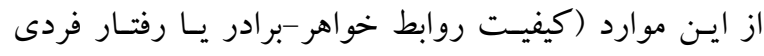
كودكs) مى تواند منجر به بروز اثر مثبتى شود.

2. prosocial behavior
بـــرفتـارىهاى كود كان مبتلا به اختلال نافرمانى مقابلهاى عمل مى كند و تعامل منفى والد-كود كك نقش مهمى در بروز اختلال

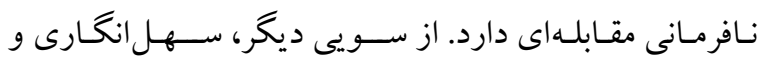
بى تفاوتى والدين نيز مى تواند ميزان بروز رفتارهاى مقابلهاى را افزايش دهـد. يُزوهشهـا نشــان مى دهد كه هر جه مادران در

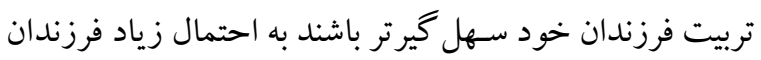

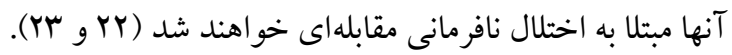

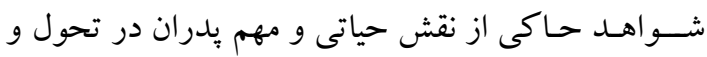

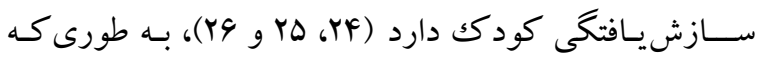
ارتباط بيشتر بين يدر و فرزند و والدگرى مناسب تر يدر به طور

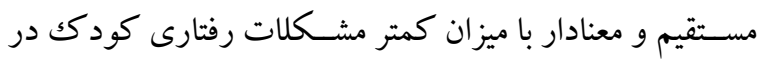

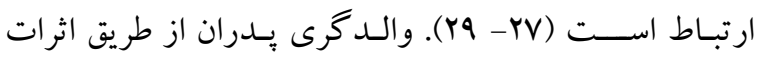

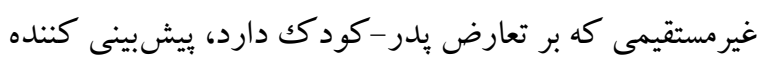

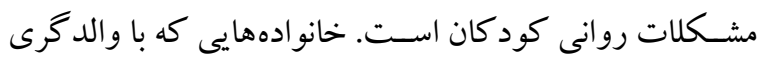

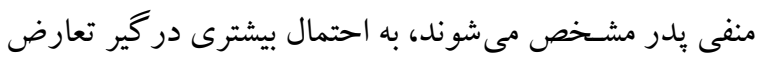

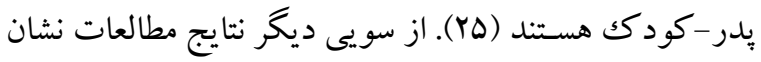

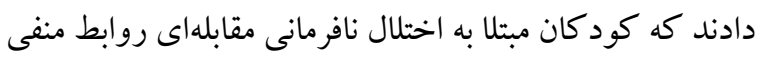

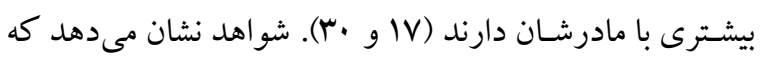
رفتارهاى والدگرى مادران (ياسخدهى مادر انه و انضباط خشن

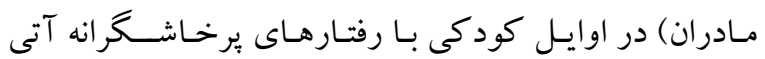
كودكان مرتبط اســت ( اسM) كـه اين نتايج نقش حياتى رابطه

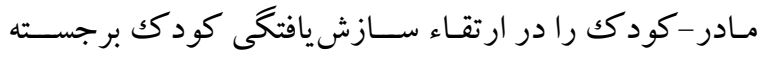
مى كند. در مجموع بر اسـاس دوجانبه بودن روابط بين كيفيت

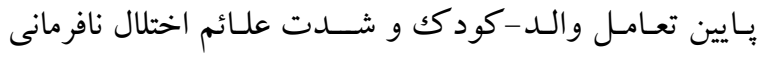
مقـابلهاى (Yr) مى توان نتيجه گرفت كه هر جقد وندر علائم اختلال

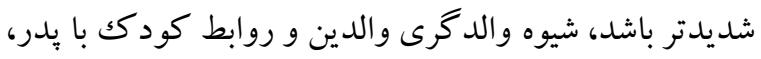

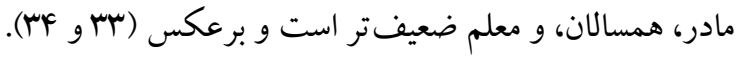

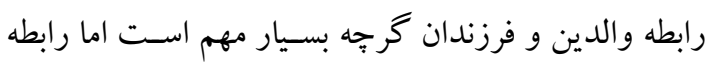
خواهر -بر ادرها' شــايد مهمتر نيز باشــــ زيرا خواهر -بر ادرها

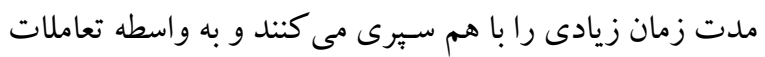

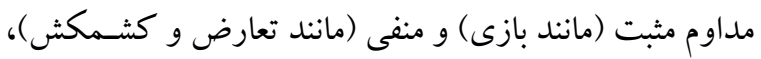


روانى صورت گرفت. ملاككهاى ورود به يُوهش شامل دامنه ســى ^ تا Y I ســال، فقدان ناتوانى جســمانى، فقدان ســاير

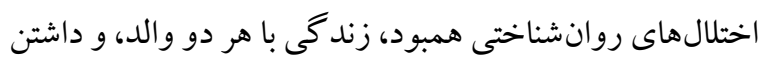

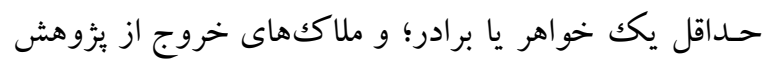
شـامل وجود اختلالات همبود در دانش آموز، مصرف داروهاى روانيزشـكى توســـ دانش آموز، تككوالد بودن، تكك فرزند

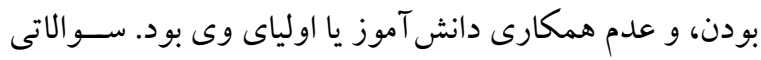

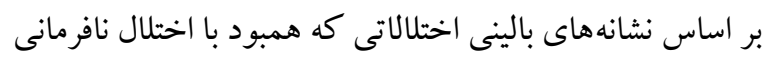

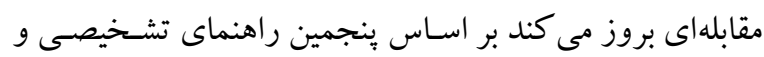

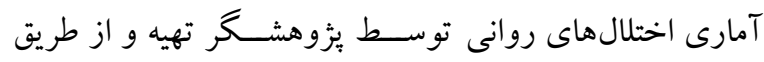

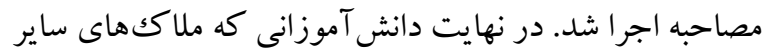

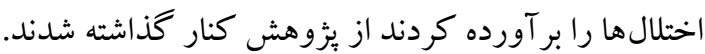

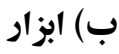
ا ـ مقياس درجسهبنــى اختلال نافرمانى مقابلهاى': اين مقياس

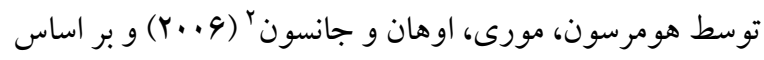

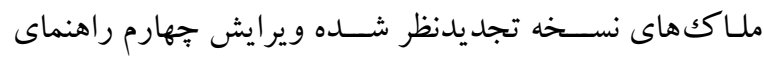
تشـخيصى و آمارى اختلالهاى روانى بر ایى تشخيص كود كان

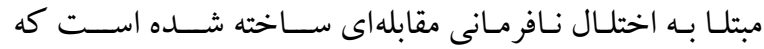
ملاككهاى اين مقياس با ملاككهاى تشـخيصسى وير ايش بنجم راهنماى تشخيصى و آمارى اختلالهاى روانى نيز منطبق است.

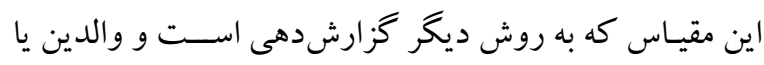

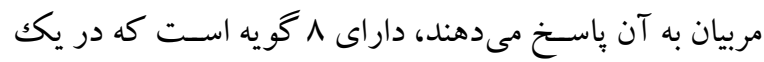

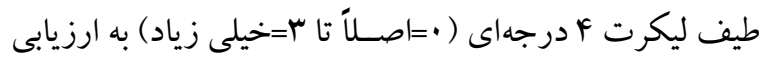

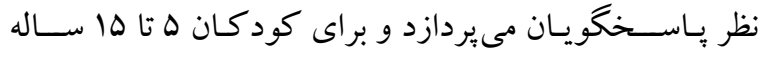

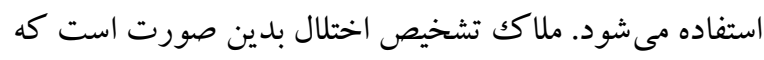

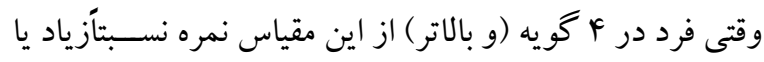

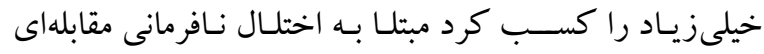

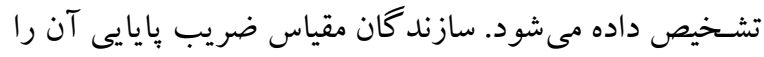

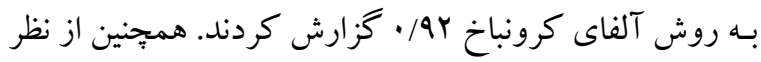

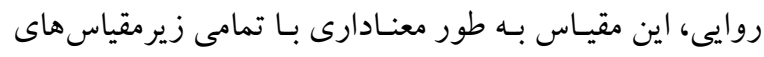

2. Hommersen, Murray, Ohan, \& Johnston
مطالعات نشــان مىدهند، وجود اختلال نافرمانى مقابله اي در •ه درصسـد موارد با اختلالات روانى نيز همراه اسـت (1)، بنابر اين شناسايى كود كان در معرض خطر نافرمانى مقابلهاى از

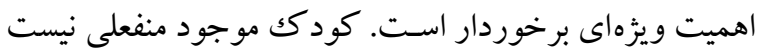
و در تعـامـل دائم بـا اطرافيـان خود قرار دارد. نقش خـانو اده و تعامل كودكك با والدين، بسيار مهم است و شناخت اين روابط در ييداكردن زمينه هاى رشـــ مشــكلات رفتارى بسـيار حائز

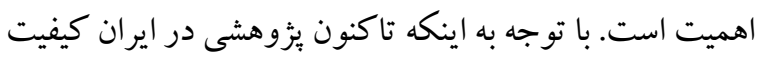
رابطه يدر و مادر با كودك و نيز كيفيت روابط خواهر -بر ادرها را در كود كان مبتلا به اختلال نافرمانى مقابلهاى نسنجيده است،

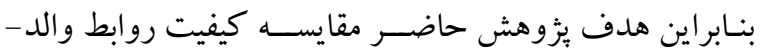

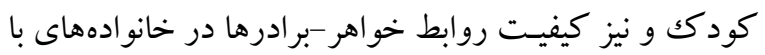

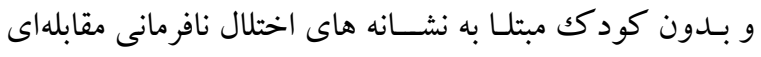

\section{روش}

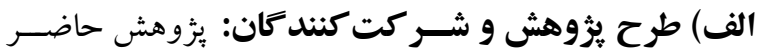
توصسيفى از نوع علّلى -مقايسـهاى اسـت. جامعه آمارى شـامل

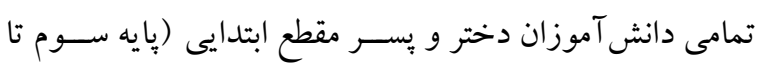
شـشـم) با و بدون نشـانه هاى اختلال نافرمانى مقابلهاى در سـال تحصـيلى 99-ه شـهرســان رودسـر و حومه (كلاجاى و

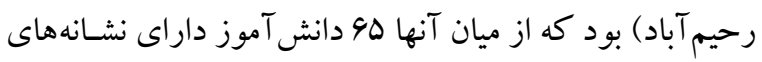

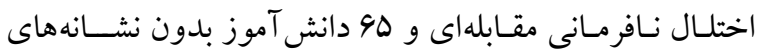
اختلال نافرمانى مقابلهاى (و ساير مشكلات هيجانى -رفتارى) از

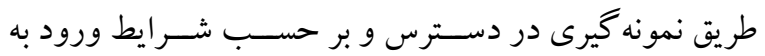

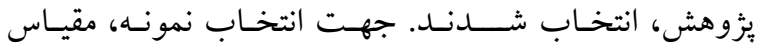
درجـهبنــى اختلال نافرمانى مقابلهاى به تمامى معلمان مدارس

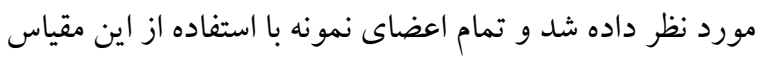

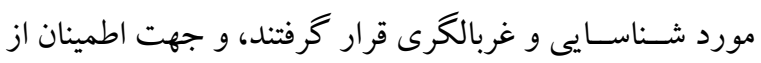
تشــخيص نهايى مصــاحبه بالينى نيمهســاختاريافته بر اسـاس

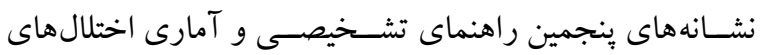




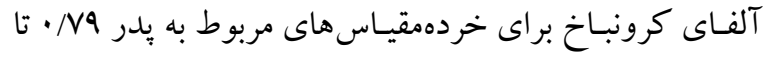

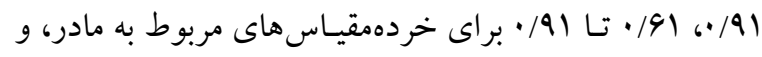
rar/ • براى رابطه كلى به دست آمد.

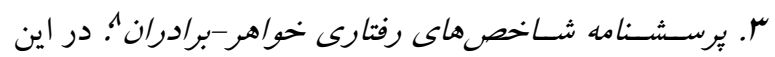
مطالعه جهت ســنجش كيفيت روابط خواهر-برادرى از فرم تجديد نظر شـده مقياس شـاخص هاى رفتارى خواهر -برادران كه توسط هترينگتون، هندرسون و ريس (1999) ساخته شده

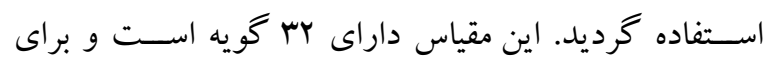

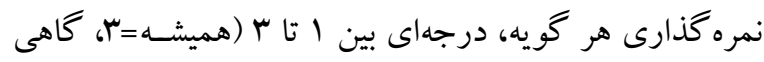

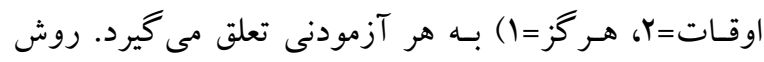

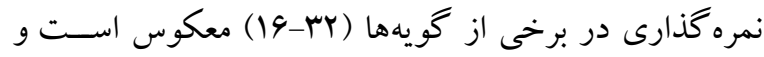

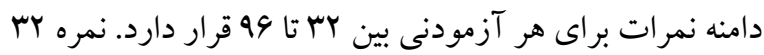

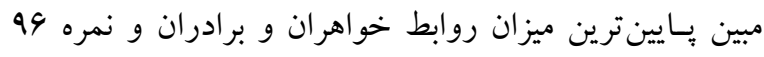

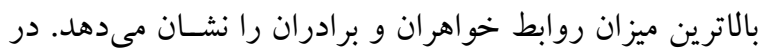

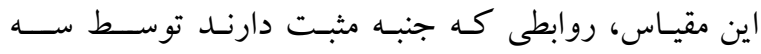
خردهمقياس مصـاحبت، همدلى، و سـرمشـقدهى / مراقبت؛ و روابطى كه جنبه منفى دارند توسـط سـه خردهمقياس رقابت،

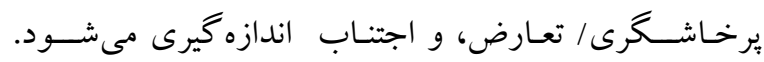

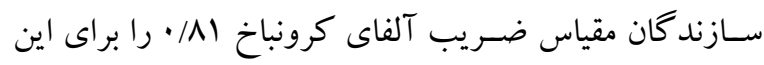
مقياس بيان كردند. ضـريب همبستخكى درونى براى دو حيطه

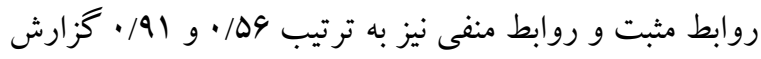
شــده اسـت (Fq). اين مقياس جهت اجرا به يكى از والدين

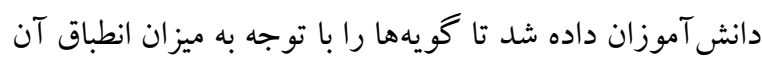
با روابط فعلى فرزند سـالمشـان نسـبت به فرزند مبتلا به اختلال نـافرمانى مقـابلـهاى (و نيز فرزند غيرمبتلا به اختلال نافرمانى تركي مقابلهاى در گروه گواه) تكميل كنند. F. مصاحبه بالينى نيمه ساختاريافته: براى تشخيص نهايى افراد نمونه و تشخيص وجود يا عدم وجود اختلال هاى روانى همبود در كودكـان حساضــــر در يزوهش از مصـــاحبـه بـالينى نيمـه

5. Father involvement

6. Resentment/Role confusion

7. Identification

8. Sibling Inventory of Behavior (SIB)
جֶكليست رفتار كودك ' (شامل مشكلات رفتارى دروننمود،

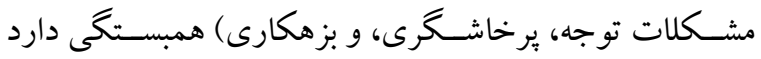

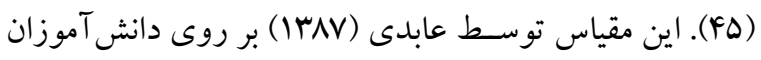
ايرانى روانسـنى و اعتباريابى شده است و ضريب پايايى اين

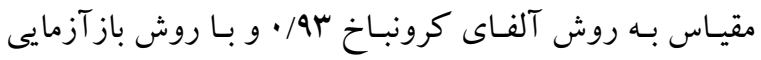

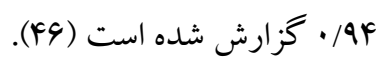
r. مقياس رابطهى والد-فرزند r.: جهت سـنجش رابطه والدين با

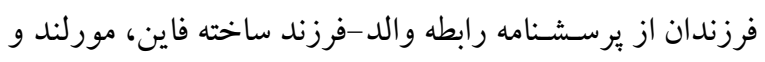

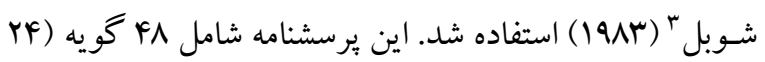

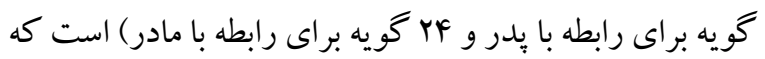
دو صــورت دارد، يكى براى ســنجيدن رابطه فرزند با مادر و

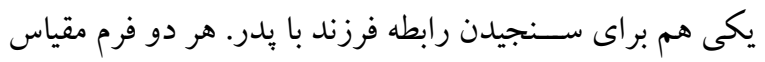

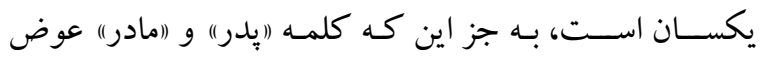
مى شــوند. خردهمقياس هاى فرم بدر عبارت هســتند از: عاطفه

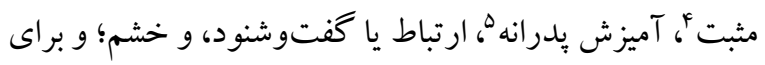

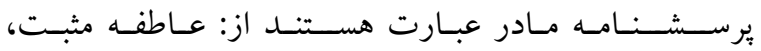

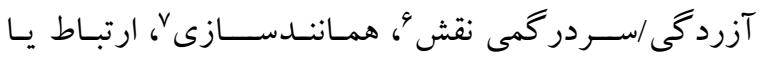

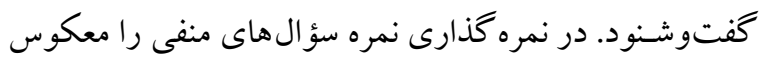

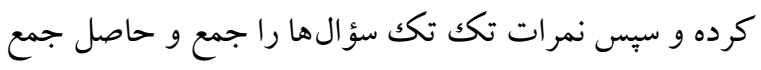
را بر تعـداد ســؤ الهـاى هر عامل براى بهدســت آوردن نمره

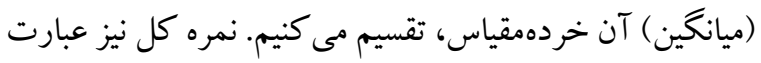

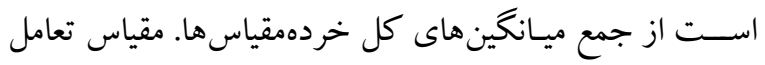

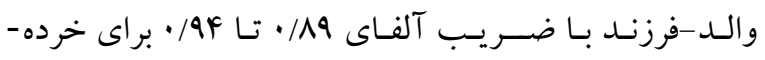

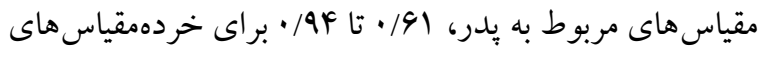

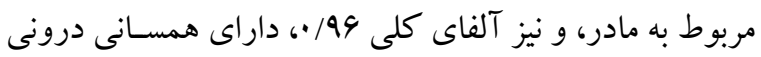
بالا اسـت. روايى مقياس تعامل ولى-فرزندى در سـحح مطلوبى

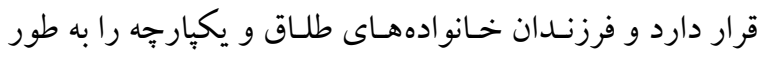

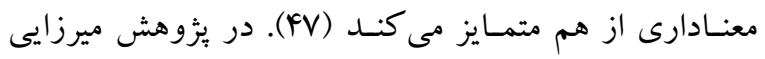
كو تنايى، شاكرى نيا و اصغرى (FN) نيز اعتبار اين ابزار با روش لري

1. Child Behavior Checklist

2. Parent-Child Relationship Scale (PCRS)

3. Fine, Moreland \& Schwebel

4. Positive affect 
مر احل به معلمان، كود كان و والدين آنها اطمينان داده شــ كه

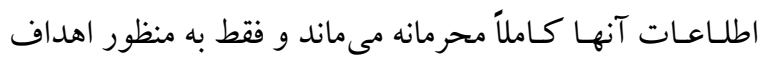
يُزوهشى استفاده مى شود. بعد از دو ماه شناسايى دانش آموزان

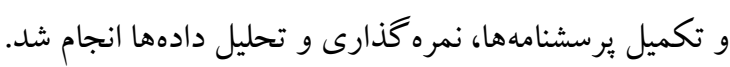

يافتهها

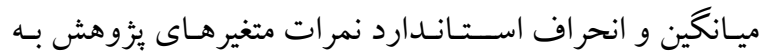
تفكيك دو گروه باو بدون نشانه هاى اختلال نافرمانى مقابلهاى در جـدول ا ارائه شــده اســت. هميجنين در اين جدول نتايج

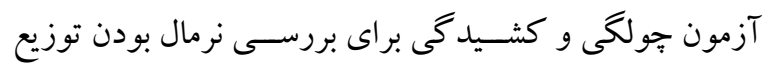

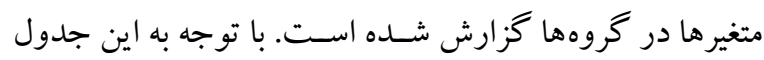

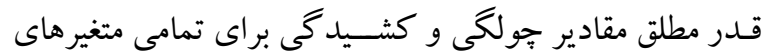

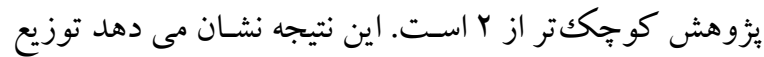

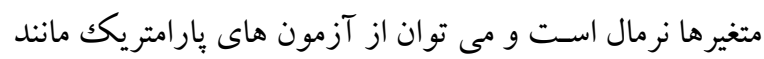
تحليل واريانس جندمتغيرى و آزمون t استفاده نمود.

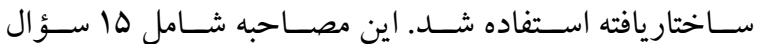
محققى سـاخته به صسورت بازياسـخ در مورد شـدت نشـانههاى

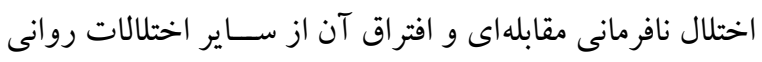
بود كه با اسـتفاده از نشـانه هاى تشـخيصـى اختلال نافرمانى

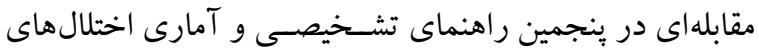

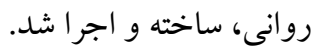
ج) روش اجرا: يس از كســب مجوزهـاى لـازم و مر اجعه به

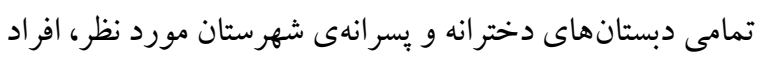

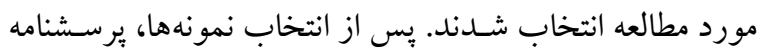
كيفيت رابطهى والد-كودك به صورت انفر ادى (در صورت

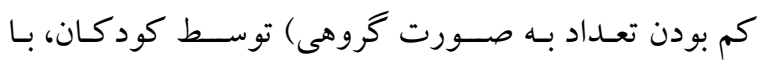

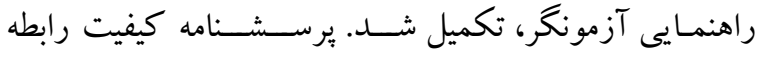

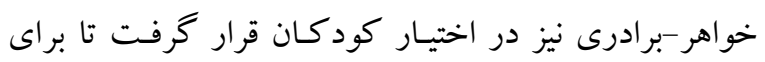

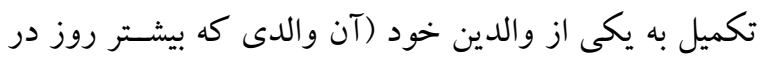

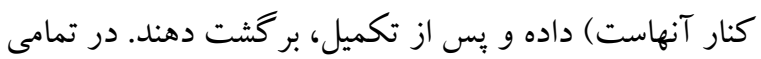

جدول ا: شاخصهاى توصيفى متغيرهاى ثيزوهش به تفكيك كروه با و بدون نشانهاى اختلال نافرمانى مقابلهاى (•rn=1r)

\begin{tabular}{|c|c|c|c|c|c|c|}
\hline كشيدكى & جولنى & انحراف استاندارد & ميانكين & كروه & متغير & \\
\hline$-1 / \lambda \cdot 1$ & $-1 / \mu N V$ & $1 / 10$ & $\Delta / \Delta F$ & با نشانههاى اختلال & \multirow{2}{*}{ عاطفه مثبت يدرانه } & \\
\hline$\cdot \mid \wedge 91$ & $-1 / 194$ & $\cdot / 09$ & G/FF & بدون نشانههاى اختلال & & \\
\hline $1 / 19$ &.$- / 991$ & $\cdot / \mathrm{AV}$ & $\Delta / r$. & با نشانههاى اختلال & \multirow[t]{2}{*}{ آميزش يدرانه } & ?;: \\
\hline$-\cdot /$ FHF & $-\cdot / F \Delta Q$ & .191 & $9 / \cdot V$ & بدون نشانههاى اختلال & & 3 \\
\hline-.1090 & $-\cdot / \Delta r Y$ & $1 / 19$ & $F / N r$ & با نشانههاى اختلال & \multirow[t]{2}{*}{ ارتباط يدرانه } & 矛 \\
\hline$-\cdot / \mu \cdot v$ &.$- / 9 r$. & $\cdot / \mathrm{V} q$ & $9 / 1 \pi$ & بدون نشانههاى اختلال & & $\hat{1}^{3}$ \\
\hline-.1901 & $-.19 \pi T$ & 1/9F & $F / \Delta F$ & با نشانههاى اختلال & \multirow[t]{2}{*}{ خشم } & 3 \\
\hline $1 / v V r$ & $-1 / \Delta 9$ & $1 / Y V$ & $\Delta / \wedge \varphi$ & بدون نشانههاى اختلال & & \\
\hline $1 / \cdot r F$ & $-1 / .94$ & $r / l r$ & r. & با نشانههاى اختلال & \multirow{2}{*}{ كيفيت رابطه بِدر-كودك } & \\
\hline$-\cdot / \cdot \Delta$ & $-\cdot 1999$ & $r / 9$. & $Y Y / Q$. & بدون نشانههاى اختلال & & \\
\hline$-\cdot /$ AYr & $-\cdot / F A F$ & $\cdot / V \Delta$ & $\Delta / V V$ & با نشانههاى اختلال & \multirow{2}{*}{ عاطفه مثبت مادرانه } & \\
\hline$\cdot / r 1 \Delta$ &.$- / 9 \Delta r$ & $\cdot / 4 F$ & $9 / 09$ & بدون نشانههاى اختلال & & \\
\hline $1 / 19 \mathrm{~V}$ & $-1 / 4 \ldots$ & $1 / 1$. & $\Delta / A$. & با نشانههاى اختلال & \multirow{2}{*}{ آزردگى /سردر گمى نقش } & ;: \\
\hline $1 / A \cdot \Lambda$ & $-1 / \cdot k \Delta$ & .199 & 9/9. & بدون نشانههاى اختلال & & $\frac{1}{3}$ \\
\hline$-\cdot / r \wedge \Delta$ & $-\cdot / \Delta F q$ & $1 / 0$ & $F / \Delta \Lambda$ & با نشانههاى اختلال & \multirow{2}{*}{ همانندسازى } & जै \\
\hline I/MTV & $-1 / Y M$ & $1 / 11$ & $\Delta / ৭ 4$ & بدون نشانههاى اختلال & & $\hat{\imath}$ \\
\hline $1 / 9 \cdot r$ & $-1 / r n$ & $\cdot / 99$ & $\Delta / \Delta \Lambda$ & با نشانههاى اختلال & \multirow{2}{*}{ ارتباط مادرانه } & $\hat{n}^{2}$ \\
\hline I/TYV & $-1 / 211$ & $\cdot / \Delta r$ & $9 / 0 r$ & بدون نشانههاى اختلال & & \\
\hline$-\cdot / 1 \wedge 9$ & $-\cdot|4|$ & $r / Y q$ & $r I / r F$ & با نشانههاى اختلال & \multirow{2}{*}{ كيفيت رابطه مادر -كودكى } & \\
\hline$\cdot / 019$ & $-1 / \cdot \cdot r$ & $r / Y 4$ & $r \Delta / 90$ & بدون نشانههاى اختلال & & \\
\hline
\end{tabular}




\begin{tabular}{|c|c|c|c|c|c|c|}
\hline.$/ \mathrm{kT}$ & $-\cdot / V Y q$ & $9 / .9$ & $F I / V r$ & با نشانههاى اختلال & \multirow{2}{*}{ كيفيت رابطه كلى والد-كودكى } & \multirow{2}{*}{ كل } \\
\hline$-.1 \cdot 19$ & $-\cdot / V a r$ & $F / F$. & $\Delta \cdot / \mathrm{IV}$ & بدون نشانههاى اختلال & & \\
\hline$-\cdot / 199$ & $\cdot / Y Y \wedge$ & $r / 90$ & $\mid Y / T Y$ & با نشانههاى اختلال & \multirow{2}{*}{ مصاحبت } & \\
\hline$-\cdot / \Delta \wedge \mu$ & $-\cdot / \mu / F$ & $r / \cdot F$ & $\mid F / F D$ & بدون نشانههاى اختلال & & \\
\hline $1 / \Gamma \cdot \Delta$ & $-1 / r V \pi$ & $r / \cdot r$ & $\mid r / A$. & با نشانههاى اختلال & \multirow{2}{*}{ 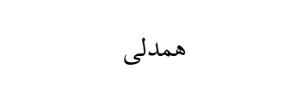 } & \\
\hline $.1 / 91$. & $-1 / \mu F \Delta$ & $1 / 1 F$ & $1 \% / 91$ & بدون نشانههاى اختلال & & \\
\hline$-\cdot / 410$ &.$/ \cdot r \mu$ & $r / \cdot \Delta$ & $\Lambda / 49$ & با نشانههاى اختلال & \multirow{2}{*}{ آموزش/مديريت } & .3: \\
\hline 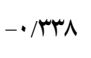 & $-\cdot / \Lambda \Delta r$ & $1 / \Delta F$ & $1 \cdot / 4 \Lambda$ & بدون نشانههاى اختلال & & \\
\hline.$/ 949$ & $-\cdot / 9 \wedge \uparrow$ & $r / \cdot F$ & $19 / 11$ & با نشانههاى اختلال & \multirow{2}{*}{ 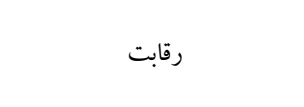 } & \\
\hline$-1 / \wedge \cdot F$ & $-1 / 4 Y V$ & $1 / 9 \mathrm{~V}$ & $1 / 1 / 9$ & بدون نشانهاى اختلال & & $\frac{1}{2}$ \\
\hline$-\cdot / Y I V$ & $-\cdot / \cdot r r$ & $r / \Delta Y$ & $1 \cdot / 1 r$ & با بشانههاى اختلال & \multirow{2}{*}{ يرخاشگرى/كشمكش } & $\frac{1}{3}$ \\
\hline $1 / .49$ & $-\cdot / 9 V 1$ & $1 / V F$ & ir & بدون نشانه هاى اختلال & & \\
\hline I/AFr & $-1 / 119$ & $r / r q$ & $\mid r / 9 V$ & با نشانههاى اختلال & \multirow{2}{*}{ اجتناب يا كناره كيرى } & \\
\hline $1 / 9 \cdot r$ & $-1 / r \cdot 1$ & $1 / \cdot r$ & $\mid F / F D$ & بدون نشانهاى اختلال & & \\
\hline $1 / Y / \Lambda$ & $-\cdot / \wedge F V$ & $\mid r / \cdot r$ & $V Y / \Delta \Delta$ & با نشانههاى اختلال & \multirow{2}{*}{ كيفيت رابطه كلى خواهر-برادر } & \\
\hline.$|4|$. &.$- / 4 \cdot 4$ & $9 / 1 V$ & $\Lambda \Delta / r \Delta$ & بدون نشانههاى اختلال & & \\
\hline
\end{tabular}

واريـانس هـاى خطـاى اين متغيرهـا در كروهها همخن اســت. همجينين نتـايج آزمون لوين براى بررسـى همكنى واريـانس

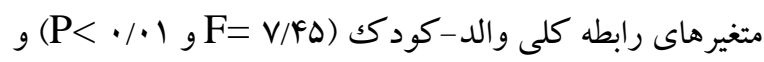

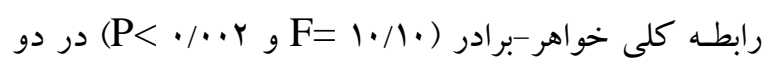
كروه معنادار اسـت اما با توجه به برابر بودن تعداد نمونه در دو كروه فرض همخنى واريـانس هـاى خطـاى اين متغيرهـا برقرار اسـت؛ بنابراين در جدول بنتايج آزمون t دو نمونه مسـتقل با بيش فرض بر ابرى واريانس ها گزارش شده است.
جهـت بررســى تفـاوت دانش آموزان مبتلـا و غير مبتلـا به نشــانـهـــاى اختلال نافرمانى مقابلهاى در متغيرهاى رابطه كلى بلى يدر-كودك، مادر-كودك،، والد-كودك و نيز خواهر -برادر از آزمون t دو نمونه مسـتقل اسـتفاده شـــــ قبل از اجراى اين آزمون، بيشفرضهاى آن مورد بررسـى و تأييد قرار گرفت. نتـايج آزمون لوين براى بررسـى همَّنى واريـانس متغيرهـاى

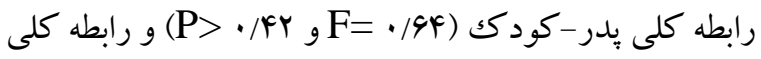

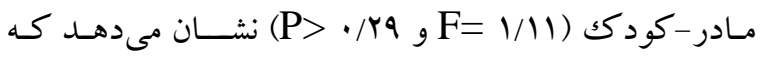

جدول ז: شاخصهاى توصيفى كروهها در متغيرهاى كيفيت رابطه كلى يدر-كودك،، مادر -كودك، والد-كودكى و خواهر -برادر

\begin{tabular}{|c|c|c|c|c|c|c|c|}
\hline سطح معنادارى & درجه & t & تفاوت ميانغين & انحراف & ميانكين & تروه & متغير \\
\hline$\% \cdot \cdot 1$ & $1 . r$ & $-V / F q$ & $-F / \Delta$. & $\begin{array}{l}r / 1 r \\
r / 9 .\end{array}$ & $\begin{array}{c}r \cdot \\
r F / Q\end{array}$ & بدان بانهان نشانهاى اختلال اختلال & كيفيت رابطه بِدر-كود كك \\
\hline$\cdot / \cdot 1$ & IrA & $-V / 99$ & $-r / 91$ & $\begin{array}{l}r / Y q \\
r / Y q\end{array}$ & $\begin{array}{l}r T / V F \\
r \Delta / 90\end{array}$ & بدون نشانهایهاى اختهال اختلال & كيفيت رابطه مادر -كود كك \\
\hline$\cdot / \cdot 1$ & IrA & $-9 / \cdot 0$ & $-\Lambda / F F$ & $\begin{array}{l}9 / .9 \\
4 / 4 .\end{array}$ & $\begin{array}{l}\text { GI/VT } \\
\Delta \cdot / I V\end{array}$ & بد با نشانههاى اختلال & كيفيت رابطه والد-كودكك \\
\hline$\% \cdot \cdot 1$ & IrA & $-V / \Delta V$ & $-1 Y / V$ & $\begin{array}{l}1 Y / \cdot H \\
9 / 1 V\end{array}$ & $\begin{array}{l}V Y / \Delta \Delta \\
\Lambda \Delta / Y \Delta\end{array}$ & با بانشانهاى اختلال & كيفيت رابطه خو اهر -برادر \\
\hline
\end{tabular}


بقيـه خردممقيـاسهاى اين متغير كه آمارمى F لوين براى آنها

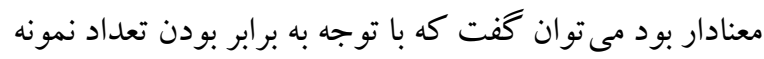
در دو گروه فرض همخنى واريـانسهاى خطاى متغيرها برقرار

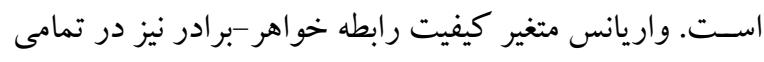
خردهمؤلفهها در دو گروه برابر است (ه> • P> (P). نتايج آزمون باكس براى بررسى ماتريس كوواريانس متغير هاى وابستهـه در بين دو گروه باو بدون نشـانه هاى اختلال نافرمانى مقابلهاى نيز

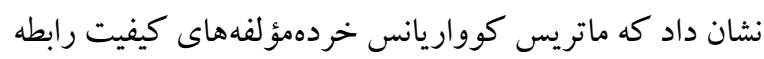

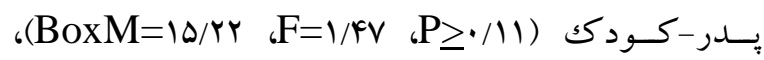

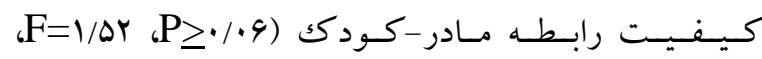
BoxM=rr/90 )، و نيـز كيـفيـت رابطسه خـواهـر-برادر

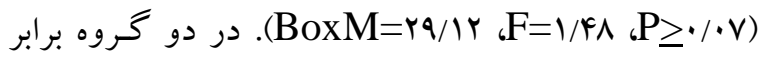
اسـت. نتـايج آزمون خىدو بارتلت براى بررسـى كرويت يا

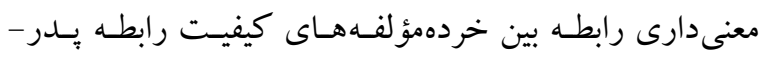
كودكى ( كودكى (X/YV)

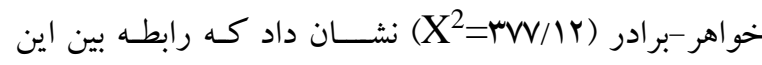

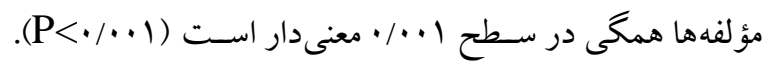

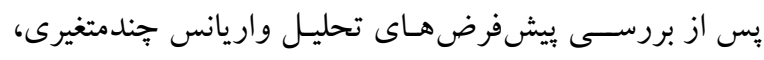

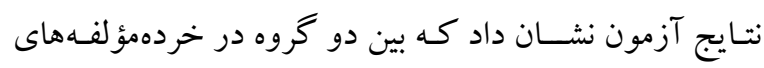

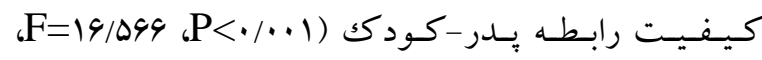

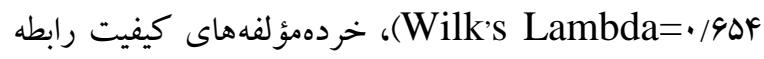
Wilk's • 1909 F=19/1FA P P P Lambda=

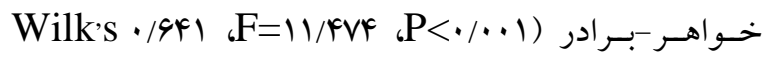
تفـاوت معنى دارى وجود دارد. نتـايج بررسـى (Lambda=

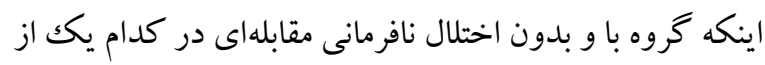

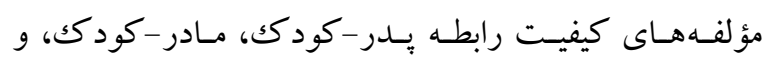

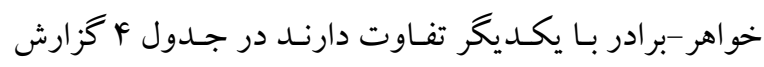

بـا توجـه به جدول rا، در متغير كيفيت رابطه يدر -كودك

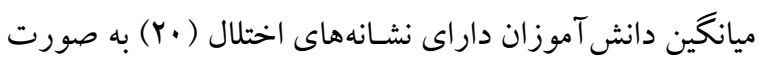

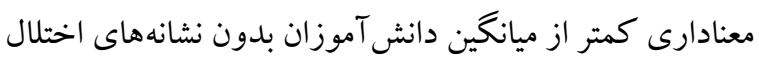

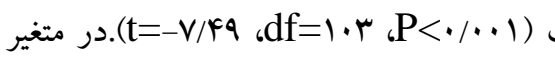
است $(Y Y / D \cdot)$ كيفيـت رابطه مـادر -كودك نيز ميـانگين دانش آموزان داراى نشانهاى اختلال (YI/VF) به صورت معنادارى كمتر از ميانگين

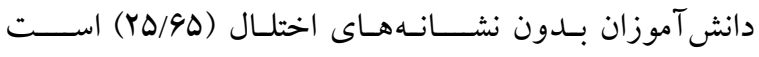

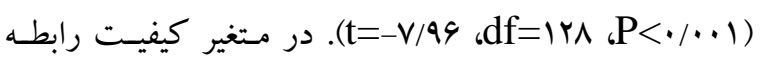
والـد-كود كك ميانگين دانش آموزان داراى نشــانه هاى اختلال

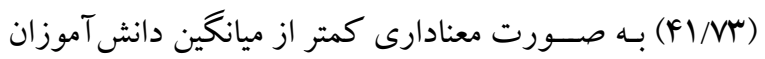

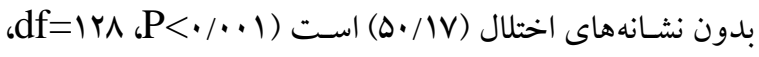

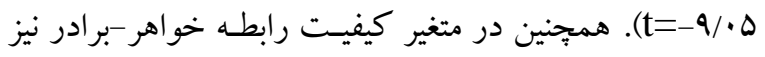

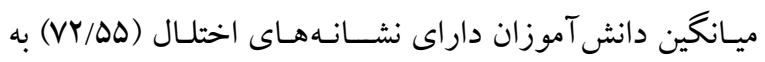
صـورت مــــــادارى كمتر از ميـانخين دانش آموزان بـدون

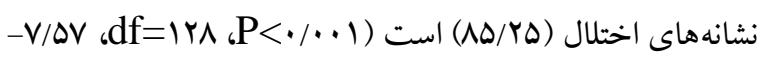
. $\mathrm{t}=$ براى مقايسه و بررسى خر دهمؤلفه هاى كيفيت رابطه بِر -

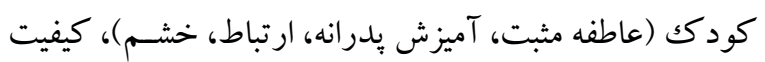

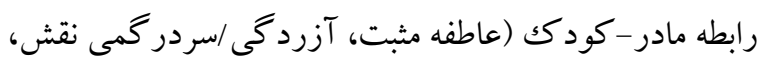

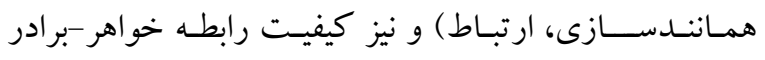

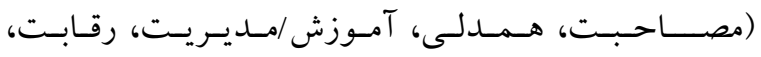
يرخاشخرى /كثمكش، اجتناب يا كنارهگيرى) در خانو ادههاى بـا و بدون فرزند داراى نشــانهاى اختلال نافرمانى مقابلهاى از تحليـل واريـانس جندمتغيره اسـتفاده شــــ قبل از اجراى اين

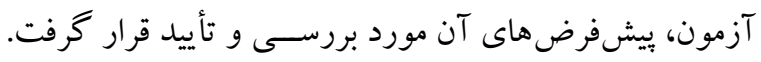
نتسايج آزمون لوين براى بررسـى همخنى واريـانس متغيرهـاى

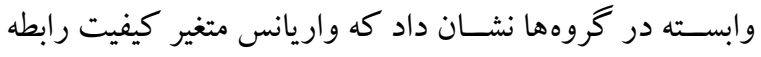

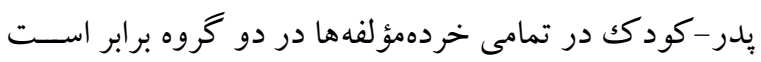

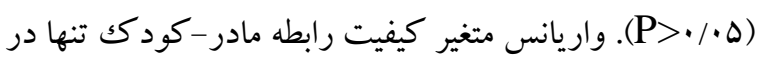

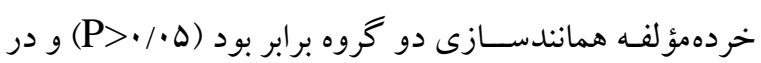


جدول با: نتايج تحليل واريانس تكمتثيرى تفاوت كروه با و بدون نشانهاى اختلال نافرمانى مقابلهاى در مؤلفهاى كيفيت رابطه بدر-كود كى،

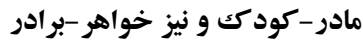

\begin{tabular}{|c|c|c|c|c|c|c|c|}
\hline اندازه اثر & $\mathbf{P}$ & $\mathbf{F}$ & ميانكين مجذورات & مجذورات خطماع & مجانغين & مجذوروات & مؤلفه \\
\hline$\cdot / 191$ & $\% \cdot \cdot 1$ & MI/9Vr & - & $1.9 / 494$ & rG/MFT & YG/MFT & عاطفه مثبت \\
\hline - MFT &.$\cdot \cdot 1$ & $41 / 19$. & $.19 \cdot 9$ & VV/or. & $r F / Q T I$ & YF/QTI & آميزش بدرانه \\
\hline ( &.$/ \cdot 1$ & GF/FFq & $\cdot / 9 \wedge 9$ & $1 Y 9 / 10$. & $9 \pi / \Delta 11$ & $9 \pi / \Delta 11$ & ارتباط يا گفتتوشنود \\
\hline$\cdot|||F|$ & $\% \cdot \cdot 1$ & $r Y / \cdot \Delta r$ & $r / V \cdot r$ & $M F Q / q \cdot \Lambda$ & $\Delta G / \wedge 9 T$ & $\Delta G / \wedge 9 Y$ & خشم \\
\hline . rar &.$/ \cdot 1$ & $\Delta r / \cdot r q$ & $\cdot /$ TVG & $F \wedge / \cdot 9 \Lambda$ & $19 / 979$ & $19 / 9 Y 9$ & عاطفه مثبت \\
\hline$\cdot 1199$ &.$\cdot \cdot 1$ & $r \Delta / F \Delta \Delta$ & - /AYF & $1 . \Delta / F F$. & $r \cdot / 99$. & $r \cdot / 99$. & آزرد گیى/سردر گمى نقش \\
\hline$\cdot / Y 19$ & $\% \cdot \cdot 1$ & $r \Delta / \mu l l$ & $1 / N T r$ & YYI/AGY & $91 / \% \cdot 0$ & $91 / \% \cdot 0$ & همانندسازى \\
\hline$\cdot / Y q V$ & $\% \cdot \cdot 1$ & $49 / 091$ & .1940 & $N|/ \mu F|$ & $r Q / \Delta M \Lambda$ & $r Q / \Delta M \Lambda$ & ارتباط يا گفتتوشنود \\
\hline$\cdot / 19 V$ & $\% \cdot \cdot 1$ & MI/raq & $\Delta / \Delta \wedge \vee$ & $V \mid \Delta / \cdot V V$ & IVD/rar & IVD/rar & مصاحبت \\
\hline.$/ M r$ & $\% \cdot 1$ & IV/VMT & $r / V \cdot V$ & HYG/DrT & $\forall \wedge / \cdots \wedge$ & $F \Lambda / \cdots \Lambda$ & هملى \\
\hline •/Yrq &.$/ \cdot 1$ & $4 . / 199$ & r/YAA & $k r \cdot / r q 9$ & $\mid r Y / \cdot \cdot 1$ & $\mid r r / \cdots 1$ & آموزش/مديريت \\
\hline . MFV & $\% \cdot \cdot 1$ & $F \mid / 9 V F$ & $9 / \cdots r$ & V9N/Far & $r \Delta Y / \cdots A$ & $r \Delta Y / \cdots \wedge$ & رقابت \\
\hline . آس/. & $\cdot / \cdot 1$ & $\Delta V / F V q$ & $F / 9 \Lambda$. & $\Delta 99 / \cdot 1 \Delta$ & r9N/99Y & Y9N/৭9Y & يرخاشخرى /كشمكش \\
\hline$.|| F \mid$ &.$\cdot \cdot 1$ & $r y / \cdots \Delta$ & r/TVQ & $\operatorname{kry} / \ldots$ & $V \cdot / \wedge 9 Y$ & $V \cdot / \wedge 9 Y$ & اجتناب يا كناره گيرى \\
\hline
\end{tabular}

كود كك در كود كان مبتلـا به اختلال نافرمانى مقابلهاى كمتر از

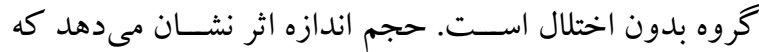
T9/\% درصـد از تغييرات عاطفه مثبت، 19/9 درصد از تغييرات

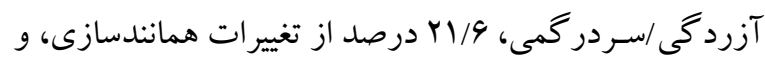

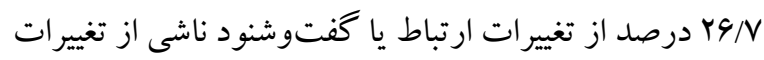

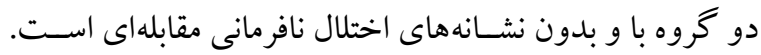

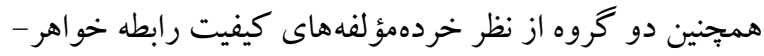

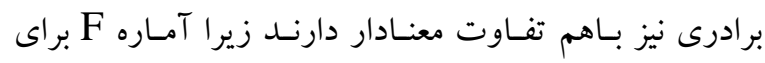

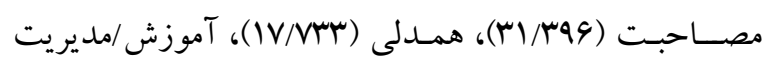

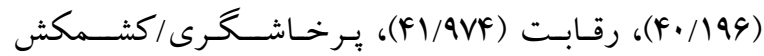

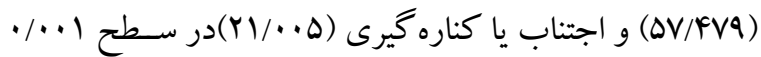
معنى دار است. مقايسه ميانگين نمر ات گروهها نشان مىدهد كه تمـامى مؤلفـهـهـاى كيفيـت رابطه خو اهر -بر ادرى در كود كان

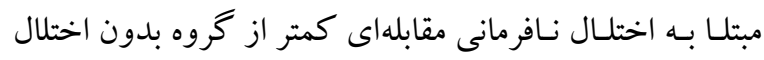

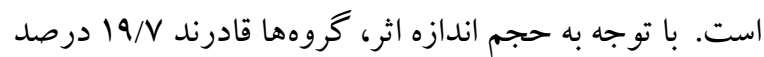

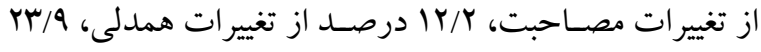
درصـد از تغييرات آموزش/مديريت، YF/V درصـد از تغييرات
بـا توجـه بـه جـدول سا، دو گروه از نظر خردهمؤلفـهــاى كيفيـت رابطه يـدر -كودك بــاهم تفاوت معنى دار دارند زيرا

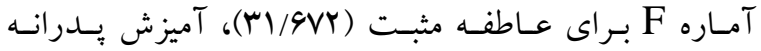

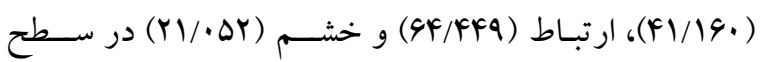

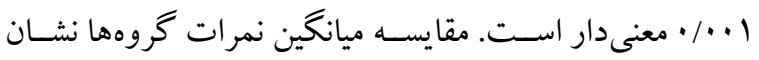
مى دهــ كـه تمـامى مؤلفـهاى كيفيت رابطه پيدر-كود كك در

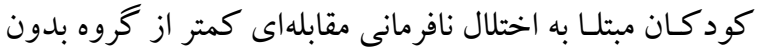

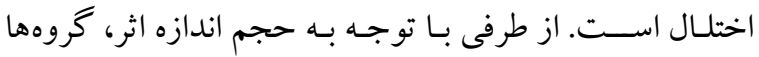

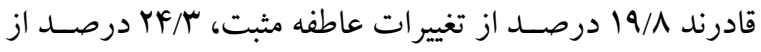

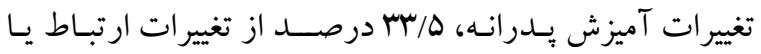

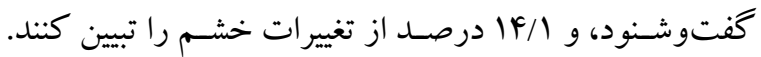

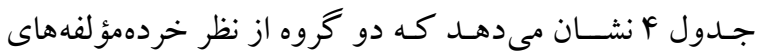
كيفيت رابطه مادر-كود كك نيز باهم تفاوت معنىدار دارند زيرا

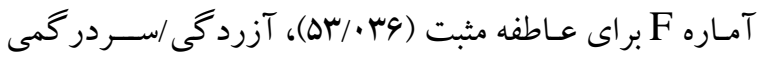

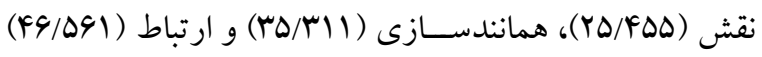

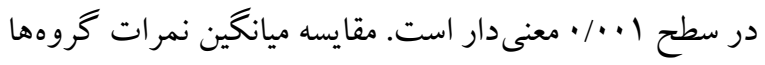

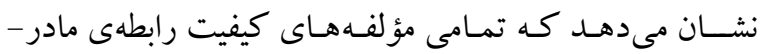


دادن اسـتقلال و ســبكك والدگرى مقتدر انه، ارتباط همزمان و طولى بســــار كم و به همان اندازه منفى با مشــكلات رفتارى

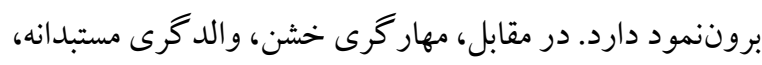

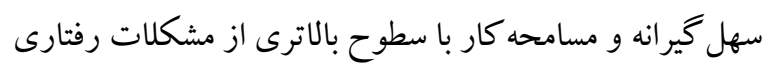

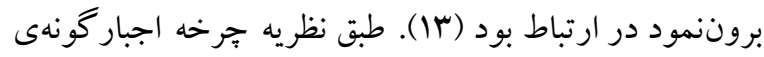

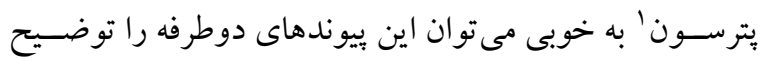

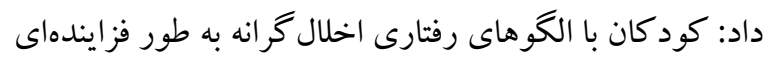

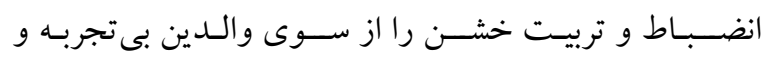

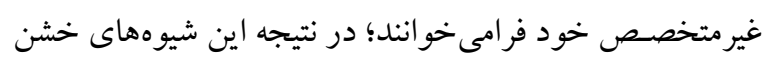

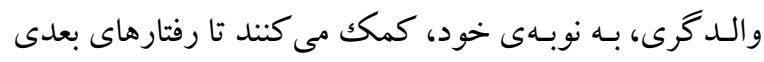

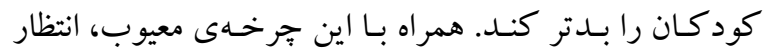

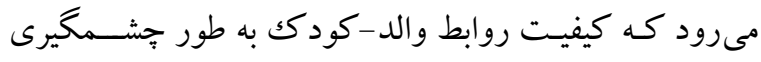
كاهش يابد كه ممكن است منجر به شديدتر شدن علائم اختلال

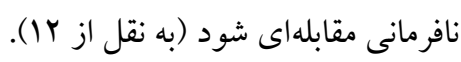

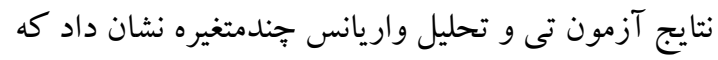
كيفيـت رابطه كلى يــدر-كود كك و نيز خردهمؤلفه هاى آن در

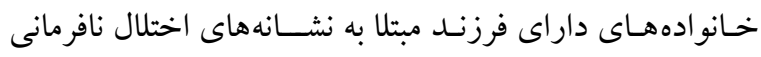

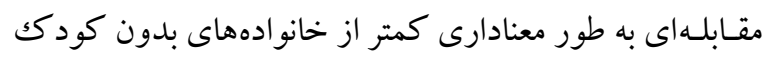

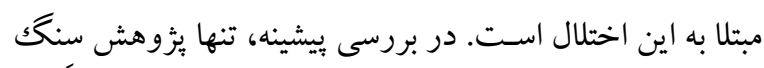

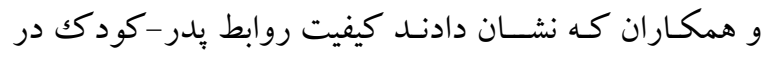
خانو ادههاى داراى كود كان مبتلا به اختلال نافرمانى مقابلهاى به به بهرد

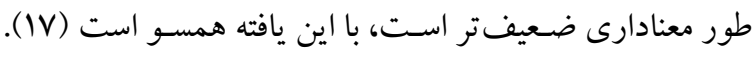

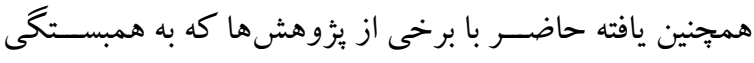

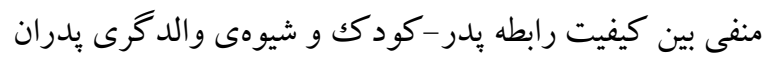

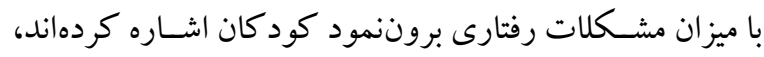

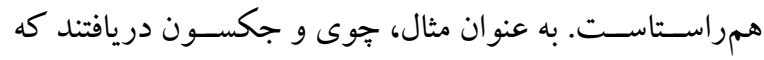

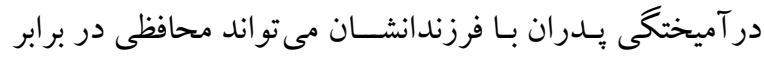
رفتارهاى بروننمود كود كان باشد بهطورى كه هرجقدر ميزان بـان

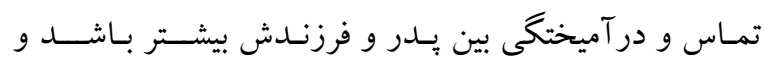

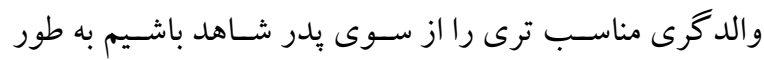

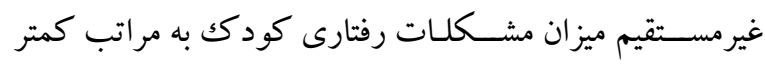

رقابت، الس درصـد از تغييرات يرخاشـخرى/كشمكش، و |F/| درصد از تغييرات اجتناب يا كناره گيرى را تبيين كنند.

\section{بحث و نتيجه كيرى}

يُزوهش حاضـر با هدف مطالعه كيفيت رابطه والد-كود كك و

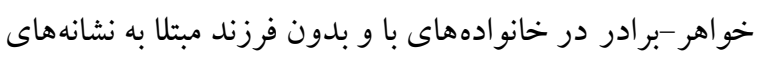

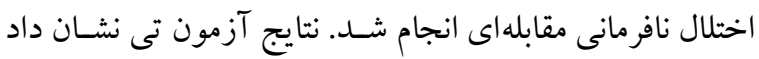

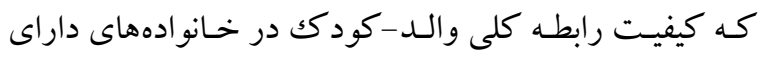
فرزنـــ مبتلـا بـه نشــانـهـهـاى اختلـال نافرمانى مقابلهاى به طور معنادارى كمتر از خانو ادههاى بدون كودكك مبتلا به اين اختلال است. اين يافته با نتايج يُزوهش سنَكَ، كاواباتا و كائو كه نشان

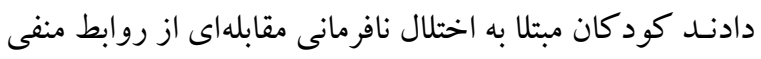
و نامناسـب والد-كود كك رنج مىبرند (IV) و همجنين با نتايج يُزوهش لى و همكاران كـه بيان كردند هرجقدر علائم اختلال نافرمانى مقابلهاى شديدتر باشد ارتباطات بين فردى كود كك (از جمله روابط والد-كود ك،، همسـال-كود كك و معلم-كود كى) ضعيفتر است (MY)، همراستا است. همجنين يزٔوهش بهروزى و همكاران نيز نشان داد كه خشونت فيزيكى و عاطفى والدين با رفتار برخاشـــ انه اين كود كان رابطه مسـتقيم معنادار دارد. طبق اين بزروهش خشـونت عاطفى نسـبت به خشـونت فيزيكى رفتار يرخاشـخر انه را ي يشبينى مي كند و نشان مىدهد كه آزار و اذيت احسـاسى و روانى كه توسط والدين اعمال مى شود از

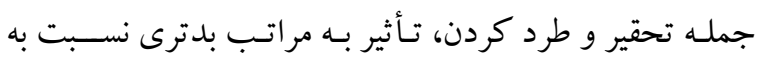

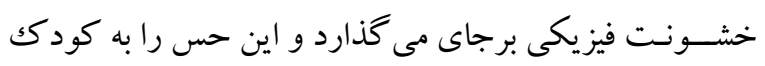

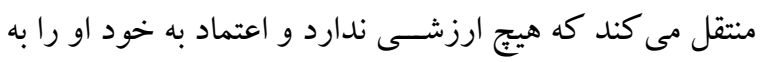
شدت بايين مى آورد (Y) (Y). در تبيين اين يـافتهه مى توان بـه بيونـدهاى طولى و دورجانبه بين علائم اختلال نافرمانى مقابلهاى و روابط والد-كود كك اشاره

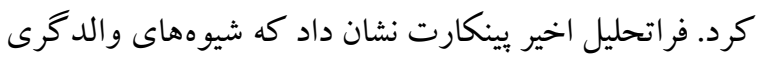

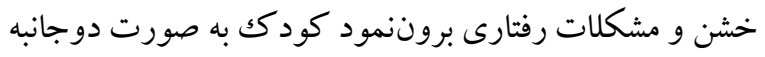

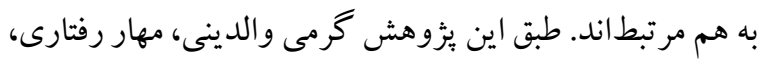


بر كيفيت روابط تأثير كذاشته و در خرخهاى دوجانبه و معيوب رفتارهاى يرخاشگرى و نافرمانى كود كان را دامن مىزند.

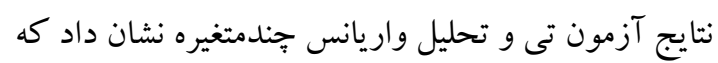

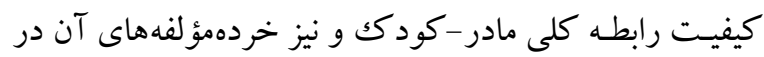

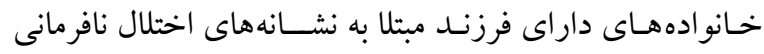

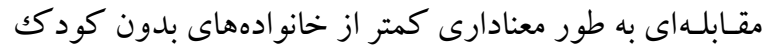

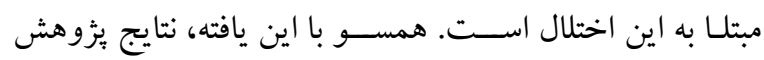

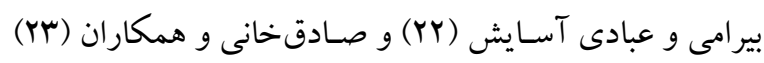

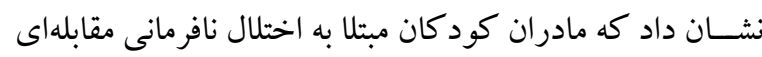

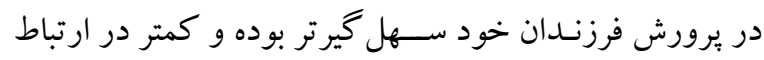

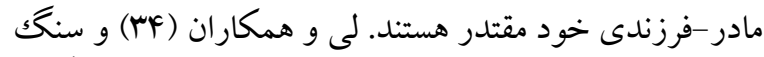

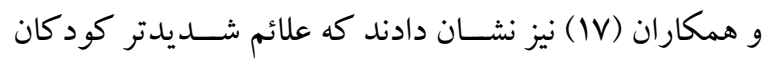

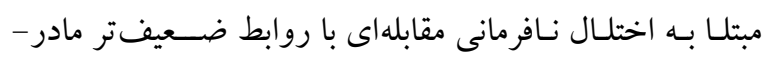

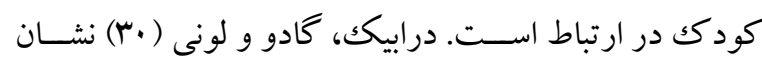

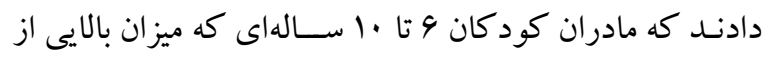
نشانه هاى اختلال نافرمانى مقابلهاى را در كود كان خود گز ارش كردند، بيشترين ميزان گسستخى عاطفى بين مادر -كود كك و

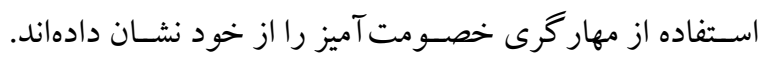
بيدار و آكجينار نيز اظهار داشـتند كه نظموانضسباط خشن مادر

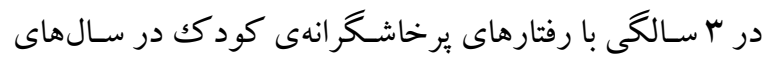

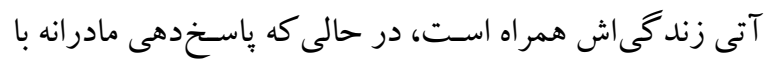

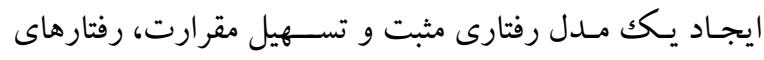

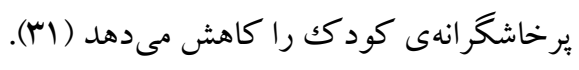

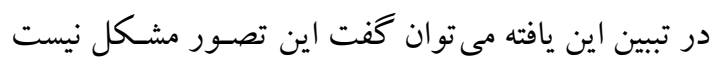

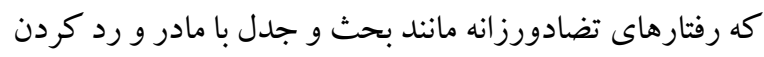

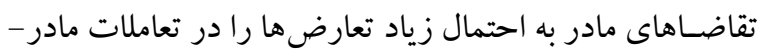
كودكك افزايش مىدهد، در نتيجه كيفيت روابط مادر -كودكى

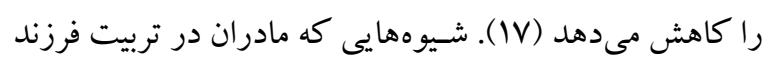

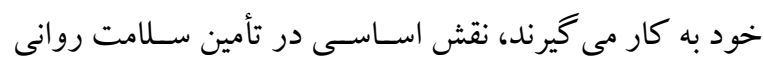
فرزنسـ و مـيز ان كيفيـت رابطسه مـادر-كودكك دارد. نتـايج ئزوهش هـاى انجـام شــــه نشــان مى دهد كه مادران كود كان

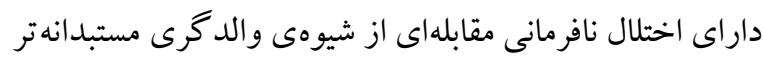

است (YV). كابررا و همكاران نيز نشان دادند كه آنجه بيشتر از حضـور يا عدم حضسور بدر در خانه اهميت دارد كيفيت رابطه

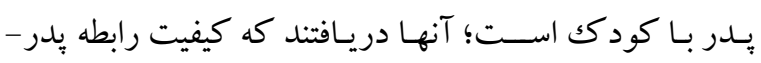
كود كك به طور مستقيم با مشكلات رفتارى كود كان و مشكلات

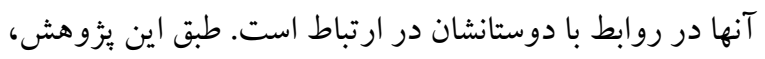

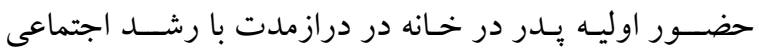
كودكك در ارتباط نبود اما در اواسـط دوران كودكى كيفيت

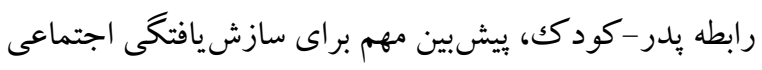

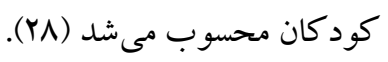
در حالى كه مطالعات بسـيار كمى به صـراحت فرايندى را كـه هــدران از طريق آن بر رفتار كود كانشــان تأثير مى خذارند

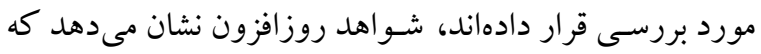

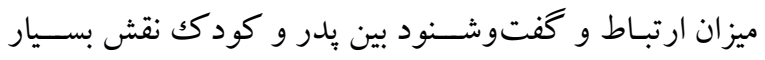

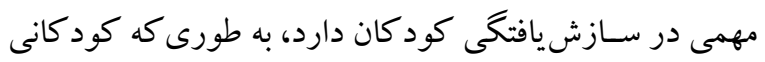
كه يدران آنها در خانه حضور دارند مشكلات رفتارى و عاطفى كمترى نسـبت به كود كان با بدران غير حاضـر در منزل دارند (Yq)؛ بنابر اين كمتر بودن ميزان ارتباط بين بدر و كودكك مبتلا بـه اختلال نافرمانى مقابلهاى بر كيفيت رابطه بدر-كود كك تأثير

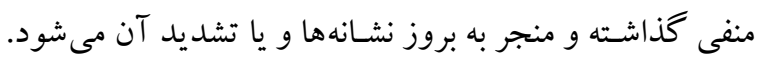

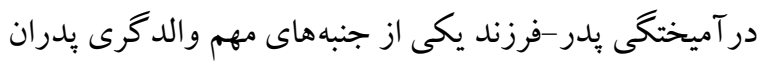

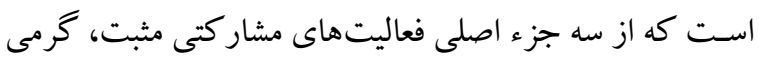

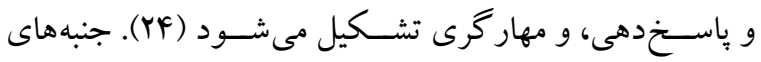

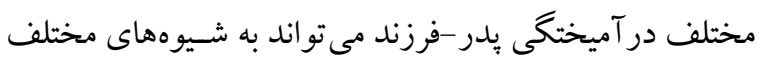

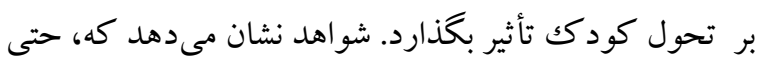

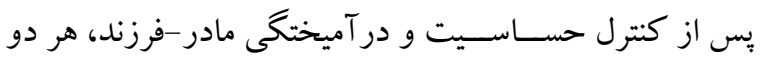

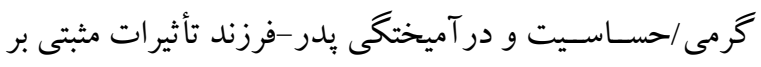

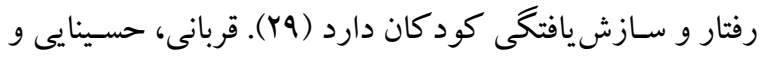

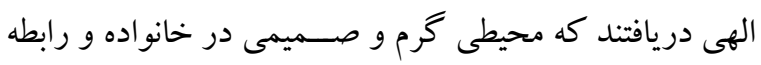
محبت آميز همر اه با شوخطبعى بين بدر و فرزند، عاملى مهم در

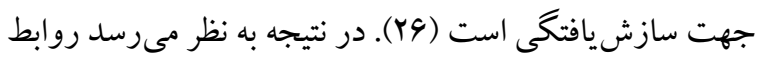

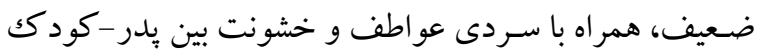


مثبت اوليه بين خواهر -برادرها به تحول مثبت شــناختى كمكك

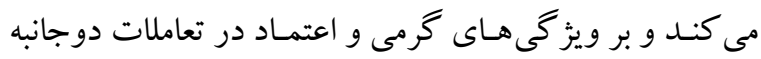

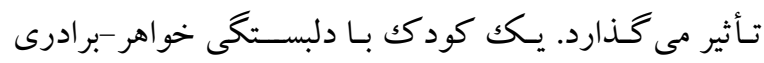

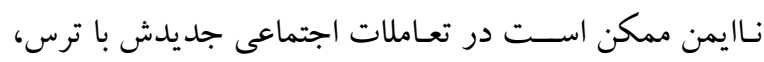

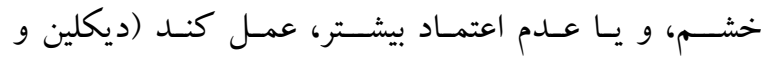

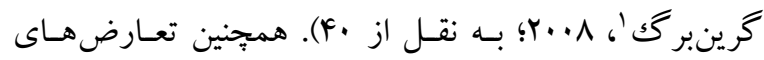

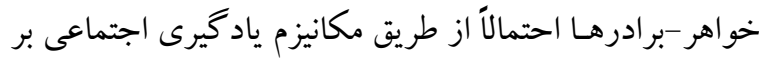

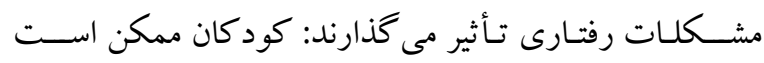

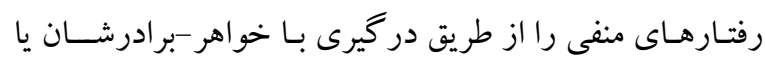
مشــاهده رفتار خصــمانهى خواهر -بر ادرشــان بياموزند و اين رفتارهاى منفى را به ساير زمينهها نيز تعميم دهند ( (F).

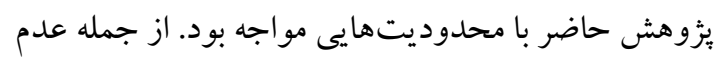

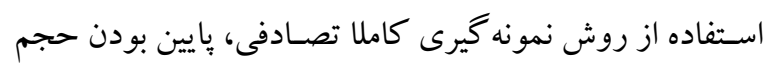
نمونسه، و و نيز محسدود بودن نمونسه تنهـا به يكك شـهـر ســــان. هميخنين بـه دليـل برابر نبودن تعـداد دختر و بســر، نتـايج اين يثروهش بــه طور مجزا در دو جنس مقــايســـه نشــــــ براى يُزوهش هاى بعدى بيشـنهاد مىشـود والدين نيز بر ایى تشخيص

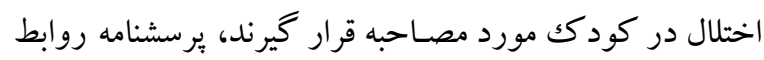
خواهر -برادرى نيز توسط هر دو والد تكميل شود، و با بررسى متغيرهـاى بزوهش حاضــر بر روى نمونههايى با حجم بالاتر و

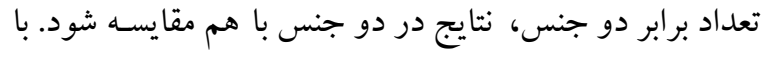

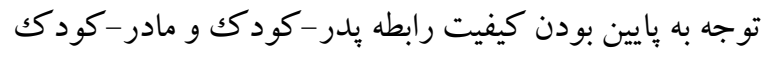

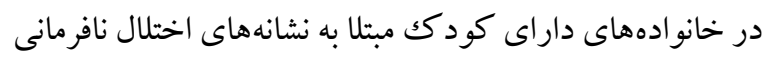
مقابلهاى بيشـنهاد مى شـود مهارتهايى همجون نحوه برخورد

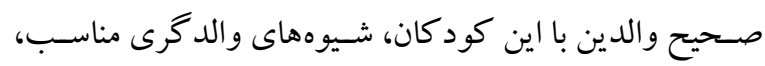
ارتباط مؤثر با كودك، و نيز حل معظلاتى كه اين والدين با آن روبرو هستسند در قالب دوره آموزشسى براى والدينى كه داراى

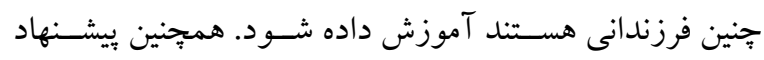
مى شـود والدين و معلمان از نقش بسسيار مهم و حياتى خواهر برادرها در بيشـيرى از بيشتر مطلع شوند و جلساتى با والدين وسين
و سـهل گيرانهتر اسـتفاده مى كنند و كمتر شيوه تربيتى مقتدرانه

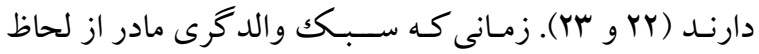
مؤلفههايى جون مر اقبت، رابطه و سـاختار نامناسب است، بستر

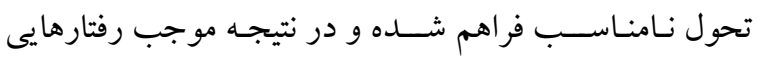
مىشود كه به عنوان منفى برجسب خورده است (Tr).

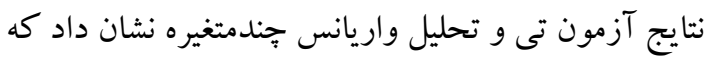
كيفيـت رابطه كلى خواهر -بر ادر و نيز خردهمؤلفـههاى آن درو

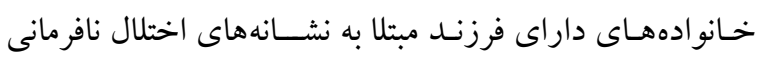

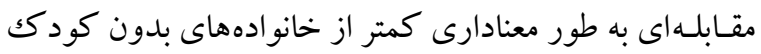

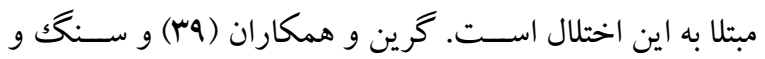
همكاران (IV) در مطالعه خود نشـان دادند كه كود كان مبتلا به اختلـال نـافرمانى مقابلهاى تعارض، تعاملات منفى و مشــكلات

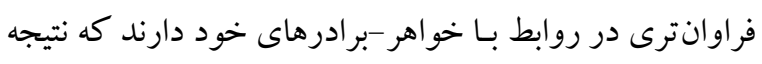
اين دو يزوهش با يافته مطالعه حاضر همسو است. يزوهشهاى

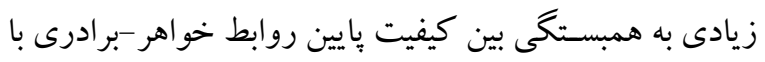

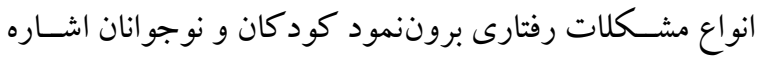

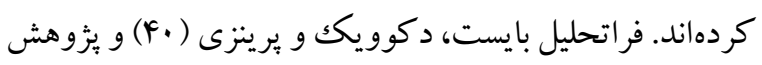

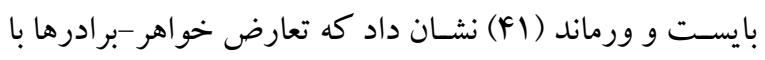
ســطوح بالاتر مشـكلات رفتارى برون نمود بعدى كودكك در

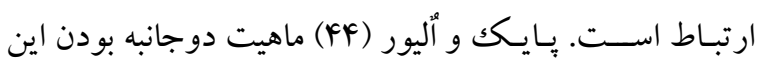

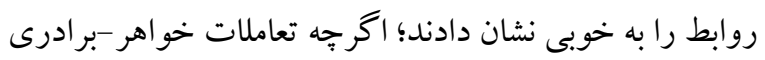

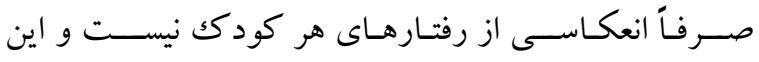
ويز گى هـاى فردى بـه وضـوح بر اين روابط دوجـانبـه تـأثير مى كذارد. رابطه بين كيفيت روابط خواهر -بر ادرى و مشكلات رفتارى برون نمود را مى توان توسـط جندين فرايند توضسيح داد. نظريه دلبستخى بيشنهاد مى كند كه همبستخى بين صميميت خو اهر -

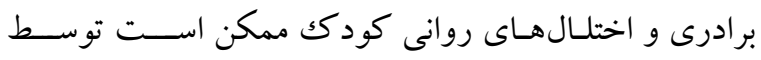
فرايندهاى تنظيم هيجان و شناخت اجتماعى توضيح داده شود. كود كان مبتلا به اختلال نافرمانى مقابلهاى در شناخت و ويردازش

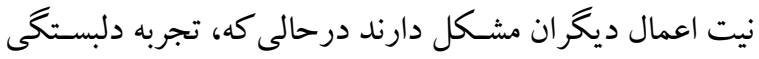

1. DeKlyen \& Greenberg 


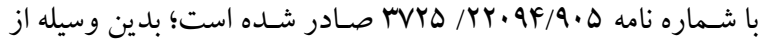

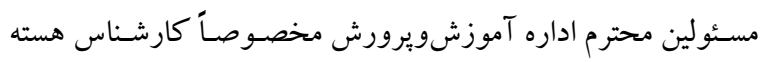

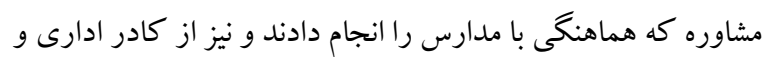

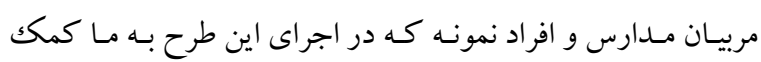
كردند، تشكر و قدردانى مى مشود.

تضاد منافع: اين يثزوهش بدون حمايت مالى سازمان يا نهاد خاصى

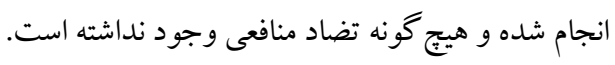

براى دركك بهتر علل تعـارض بين كودكان و روشهـاى حل تعارض بين آنها بر گزار شود. تشـكر و قدردانى: مطالعه حاضـر بر گرفته از باياننامه كارشـناسى

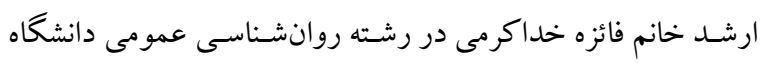

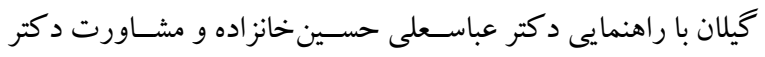

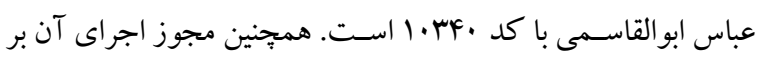

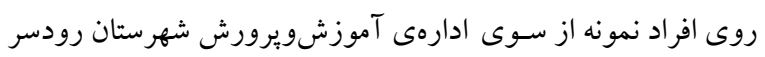




\section{References}

1. Christenson JD, Crane DR, Malloy J, Parker S. The cost of oppositional defiant disorder and disruptive behavior: A review of the literature. J Child Fam Stud. 2016; 25(9): 2649-2658. [Link]

2. Steiner H, Remsing L. Practice parameter for the assessment and treatment of children and adolescents with oppositional defiant disorder. J Am Acad Child Adolesc Psychiatry. 2007; 46(1): 126-41. [Link]

3. Schoorl J, van Rijn S, de Wied M, van Goozen S, Swaab H. Boys with oppositional defiant disorder/conduct disorder show impaired adaptation during stress: An executive functioning study. Child Psychiatry Hum Dev. 2018; 49(2): 298-307. [Link]

4. Booker JA, Capriola-Hall NN, Dunsmore JC, Greene RW, Ollendick TH. Change in maternal stress for families in treatment for their children with oppositional defiant disorder. J Child Fam Stud. 2018; 27(8): 2552-2561. [Link]

5. Paliziyan A, Honarman MM, Arshadi N. Symptoms of oppositional defiant in students: the predicting role of emotion regulation, schema, and vandalism. Int J High Risk Behav Addict. 2018; 7(3): e67691. [Link]

6. Demmer DH, Hooley M, Sheen J, McGillivray JA, Lum, JAG. Sex differences in the prevalence of oppositional defiant disorder during middle childhood: A Meta-Analysis. J Abnorm Child Psychol. 2017; 45(2): 313-325. [Link]

7. Smith TE, Lee CA, Martel MM, Axelrad ME. ODD symptom network during preschool. J Abnorm Child Psychol. 2017; 45(4): 743-748. [Link]

8. Skoulos V, Tryon G. Social skills of adolescents in special education who display symptoms of oppositional defiant disorder. Journal of American Secondary Education. 2007; 35(2): 103-115. [Link]

9. Leadbeater BJ, Ames ME. The longitudinal effects of oppositional defiant disorder symptoms on academic and occupational functioning in the transition to young adulthood. J Abnorm Child Psychol. 2017; 45(4): 749-763. [Link]

10. Groenman AP, Janssen TWP, Oosterlaan J. Childhood psychiatric disorders as risk factor for subsequent substance abuse: A meta-analysis. J Am Acad Child Adolesc Psychiatry. 2017; 56(7): 556569. [Link]

11. Déry M, Lapalme M, Jagiellowicz J, Poirier M, Temcheff C, Toupin J. Predicting depression and anxiety from oppositional defiant disorder symptoms in elementary school-age girls and boys with conduct problems. Child Psychiatry Hum Dev. 2017; 48(1): 53-62. [Link]

12. Lin X, Li L, Chi P, Wang Z, Heath MA, Du H, et al. Child maltreatment and interpersonal relationship among Chinese children with oppositional defiant disorder. Child Abuse Negl. 2016; 51: 192-202. [Link]

13. Pinquart M. Associations of parenting dimensions and styles with externalizing problems of children and adolescents: An updated meta-analysis. Dev Psychol. 2017; 53(5): 873-932. [Link]

14. Lifford KJ, Harold GT, Thapar A. Parent-child relationships and ADHD symptoms: A longitudinal analysis. J Abnorm Child Psychol. 2008; 36(2): 285-296. [Link]

15. McKinney C, Stearns M, Szkody E. Maltreatment and affective and behavioral problems in emerging adults with and without oppositional defiant disorder symptoms: mediation by parent-child relationship quality. J Interpers Violence. 2018; 1-21. [Link]

16. Li L, Lin X, Chi P, Heath MA, Fang X, Du H, et al. Maltreatment and emotional and behavioral problems in chinese children with and without oppositional defiant disorder: The mediating role of the parent-child relationship. J Interpers Violence. 2016; 31(18): 2915-2939. [Link]

17. Tseng WL, Kawabata Y, Gau SS-F. Social adjustment among taiwanese children with symptoms of ADHD, ODD, and ADHD comorbid with ODD. Child Psychiatry Hum Dev. 2011; 42(2): 134-151. [Link]

18. Kildare CA, Middlemiss W. Impact of parents mobile device use on parent-child interaction: A literature review. Comput Human Behav. 2017; 75: 579-593. [Link]

19. Lund JI, Day KL, Schmidt LA, Saigal S, Van Lieshout RJ. Adult mental health outcomes of child sexual abuse survivors born at extremely low birth weight. Child Abuse Negl. 2016; 59: 36-44. [Link] 
20. Dunsmore JC, Booker JA, Ollendick TH. Parental emotion coaching and child emotion regulation as protective factors for children with oppositional defiant disorder. Soc Dev. 2013; 22(3): 444-466. [Link]

21. Behroozy N, Farzadi F, Faramarzi H. Investigating the causal relationship of parents' physical and emotional violence with anger management and aggressive behavior of children with oppositional defiant disorder mediated by parent-child relationship and empathy. Quarterly Journal of Child Mental Health. 2016; 3(3): 43-58. [Persian]. [Link]

22. Bayrami M, Ebadi Asayesh M. A comparison of the rate of oppositional defiant disorder (ODD) with regard to mothers' child rearing styles. Woman and Family Studies. 2009; 1(4): 49-62. [Persian]. [Link]

23. Sadeghkhani A, Aliakbari Dehkordi M, Jooybari A. Disorder and mothers of normal students of the same age in ilam city. Psychology of Exceptional Individuals. 2012; 2(6): 95-114. [Persian]. [Link]

24. Barker B, Iles JE, Ramchandani PG. Fathers, fathering and child psychopathology. Curr Opin Psychol. 2017; 15: 87-92. [Link]

25. Yin X, Li Z, Su L. Fathers' parenting and children's adjustment: The mediating role of father-child conflict. Soc Behav Pers. 2012; 40(8): 1401-1408. [Link]

26. Ghorbani R, Hosseinaei A, Elahi B. The relationship between father humor and coping styles with the level of children adaptation. Quarterly Journal of Child Mental Health. 2017; 4(2): 92-103. [Persian]. [Link]

27. Choi JK, Jackson AP. Fathers' involvement and child behavior problems in poor African American single-mother families. Child Youth Serv Rev. 2011; 33(5): 698-704. [Link]

28. Cabrera NJ, Cook GA, McFadden KE, Bradley RH. Father residence and father-child relationship quality: peer relationships and externalizing behavioral problems. Fam Sci. 2011; 2(2): 109-119. [Link]

29. Flouri E, Midouhas E, Narayanan MK. The relationship between father involvement and child problem behaviour in intact families: A 7-year cross-lagged study. J Abnorm Child Psychol. 2016; 44(5): 10111021. [Link]

30. Drabick DAG, Gadow KD, Loney J. Source-specific oppositional defiant disorder: comorbidity and risk factors inreferred elementary schoolboys. J Am Acad Child Adolesc Psychiatry. 2007; 46(1): $92-$ 101. [Link]

31. Baydar N, Akcinar B. Reciprocal relations between the trajectories of mothers' harsh discipline, responsiveness and aggression in early childhood. J Abnorm Child Psychol. 2018; 46(1): 83-97. [Link]

32. Besemer S, Loeber R, Hinshaw SP, Pardini DA. Bidirectional associations between externalizing behavior problems and maladaptive parenting within parent-son dyads across childhood. $\mathrm{J}$ Abnorm Child Psychol. 2016; 44(7): 1387-1398. [Link]

33. Brown CA, Granero R, Ezpeleta L. The reciprocal influence of callous-unemotional traits, oppositional defiant disorder and parenting practices in preschoolers. Child Psychiatry Hum Dev. 2017; 48(2): 298 307. [Link]

34. Li L, Lin X, Hinshaw SP, Du H, Qin S, Fang X. Longitudinal associations between oppositional defiant symptoms and interpersonal relationships among Chinese children. J Abnorm Child Psychol. 2018; 46(6): 1267-1281. [Link]

35. Howe N, Ross HS, Recchia H. Sibling relations in early and middle childhood. In: Smith PK, Hart CR, editor. The Wiley-Blackwell handbook of childhood social development. 2th ed. New Jersey: WileyBlackwell; 2010, pp: 356-372. [Link]

36. Feinberg ME, Solmeyer AR, McHale SM. The third rail of family systems: sibling relationships, mental and behavioral health, and preventive intervention in childhood and adolescence. Clin Child Fam Psychol Rev. 2012; 15(1): 43-57. [Link]

37. Woodard T, Copp JE. Maternal incarceration and children's delinquent involvement: The role of sibling relationships. Child Youth Serv Rev. 2016; 70: 340-348. [Link]

38. Caspi J. Sibling aggression: assessment and treatment. New York: Springer Publishing Company; 2012, pp: 1-23. [Link]

39. Greene RW, Biederman J, Zerwas S, Monuteaux MC, Goring JC, Faraone SV. Psychiatric comorbidity, family dysfunction, and social impairment in referred youth with oppositional defiant disorder. Am J Psychiatry. 2002; 159(7): 1214-1224. [Link] 
40. Buist KL, Deković M, Prinzie P. Sibling relationship quality and psychopathology of children and adolescents: A meta-analysis. Clin Psychol Rev. 2013; 33(1): 97-106. [Link]

41. Buist KL, Vermande M. Sibling relationship patterns and their associations with child competence and problem behavior. J Fam Psychol. 2014; 28(4): 529-537. [Link]

42. Piotrowski CC, Tailor K, Cormier DC. Siblings exposed to intimate partner violence: Linking sibling relationship quality \& child adjustment problems. Child Abuse Negl. 2014; 38(1): 123-134. [Link]

43. Harper JM, Padilla-Walker LM, Jensen AC. Do siblings matter independent of both parents and friends? Sympathy as a mediator between sibling relationship quality and adolescent outcomes. J Res Adolesc. 2016; 26(1): 101-114. [Link]

44. Pike A, Oliver BR. Child behavior and sibling relationship quality: a cross-lagged analysis. J Fam Psychol. 2017; 31(2): 250-255. [Link]

45. Hommersen P, Murray C, Ohan JL, Johnston C. Oppositional defiant disorder rating scale: preliminary evidence of reliability and validity. J Emot Behav Disord. 2006; 14(2): 118-125. [Link]

46. Faramarzi S, Abedi A, Ghanbari A. Mother communication patterns and oppositional defiant disorder of children. Medical Journal of Tabriz University of Medical Sciences. 2012; 34(2): 90-96. [Persian]. [Link]

47. Fine MA, Moreland JR, Schwebel AI. Long-term effects of divorce on parent-child relationships. Dev Psychol. 1983; 19(5): 703-713. [Link]

48. Mirzaei F, Shakerinia I, Asghari F. The associations between parent-child relationship and aggressive behavior among students. Quarterly Journal of Child Mental Health. 2016; 2(4): 21-34. [Persian]. [Link]

49. Hetherington EM, Henderson SH, Reiss D, Anderson ER, Bridges M, Chan RW, et al. Adolescent siblings in stepfamilies: Family functioning and adolescent adjustment. Monogr Soc Res Child Dev. 1999; 64(4): 1-222. [Link] 